\title{
EFFECT OF SPEXIN TREATMENT ON CARDIOMETABOLIC CHANGES IN OBESE TYPE 2 DIABETIC RATS
}

\author{
By \\ Khaled Abd El-Fattah Abul-Fadle ${ }^{1 *}$, Nour El-Huda A. Mohammed ${ }^{1}$, \\ Radwa M. Al-Sayed ${ }^{1}$, Maha M. Abdul-Rahman ${ }^{2}$ and Azza Ismael Farag ${ }^{2}$ \\ ${ }^{1}$ Department of Physiology, Faculty of Medicine, Zagazig University, Zagazig, Egypt \\ ${ }^{2}$ Department of Human Anatomy and Embryology, Faculty of Medicine, Zagazig \\ University, Zagazig, Egypt
}

*Dr Khaled Abdelfattah Abulfadle E-mail: khafadle@gmail.com

\begin{abstract}
Background: Spexin is a peptide hormone that was expressed in brain regions and peripheral tissues of many species including human and rat. Several studies investigated its blood level changes with obesity and type 2 diabetes, but few studies assessed its effect on cardiometabolic, histological and morphometric changes in diabetes with some controversies in their results.

Objective: To explore the effect of spexin treatment on cardiometabolic, histological and morphometric changes of pancreas and heart tissue in obese type 2 diabetic rats, and the possible mechanisms involved.

Materials and Methods: Thirty adult male albino rats were divided randomly into 5 equal groups; control (fed ordinary laboratory chow along this 8 weeks' study), diabetic [fed high fat diet along this 8 weeks' study, but at the start of the 4th week, overnight fasted rats were injected with a single streptozotocin injection intraperitoneally $(40 \mathrm{mg} / \mathrm{kg}$ body weight, dissolved in $0.01 \mathrm{M}$ citrate buffer, $\mathrm{pH} 4.5)$ to induce diabetes], diabetic metformin-treated [rats were managed as in diabetic group and in addition to that, metformin was given orally ( $300 \mathrm{mg} / \mathrm{kg} / \mathrm{day}$ ) by oral gavage to rats for 4 weeks from the start of 5 th week to the end of 8th week], diabetic vildagliptin treated [rats were manipulated as in diabetic group and in addition to that, vildagliptin was given orally $(10 \mathrm{mg} / \mathrm{kg} / \mathrm{day})$ using oral gavage to rats for 4 weeks from the start of 5 th week to the end of 8th week], and diabetic spexin treated [rats were managed as in diabetic group and in addition to that, spexin dissolved in normal saline was injected intraperitoneally ( $35 \mu \mathrm{g} / \mathrm{kg} / \mathrm{day}$ ) for 4 weeks from the start of 5th week to the end of 8th week] groups. For histological, immunohistochemical and morphometric examinations, fresh heart and pancreatic specimens were collected from rats that were sacrificed.
\end{abstract}

Results: In diabetic group, a significant increase was detected in final body mass index, serum glucose, serum insulin, homeostasis model assessment-insulin resistance, serum total cholesterol, serum triglycerides, serum low density lipoprotein, atherogenic index, serum dipeptidyl peptidase-IV, serum tumor necrosis factor alpha $\square$ serum interleukin-1 beta, serum malondialdehyde, serum lactate dehydrogenase, serum creatine kinase-myoglobin binding and mean arterial blood pressure, with a significant decrease in homeostasis model assessment-beta cell function $\square \square$ serum high density lipoprotein, serum superoxide dismutase and serum spexin in comparison to that in the control group. With spexin treatment (as well as with the administration of standard drugs metformin and vildagliptin), all these changes were reversed significantly in comparison with those in the diabetic group. Diabetes induced histopathological changes in cardiac muscle and pancreatic structure which were ameliorated by treatment with spexin as well as with the standard anti-diabetic drugs (metformin and vildagliptin). The morphometric analysis confirmed the histopathological results, as a statistically significant difference was detected in area percent of collagen deposition, area percent of insulin immune-reaction in pancreas and cardiac muscle Bax expression between 
both diabetic group and all other groups, with no statistically significant difference between diabetic metformin treated, diabetic vildagliptin treated and diabetic spexin treated groups.

Conclusion: Spexin ameliorated diabetes induced deleterious cardiometabolic, histopathological and morphometric disturbances. The anti-obesity, dipeptidyl peptidase-IV inhibitory, hypoglycemic, hypolipidemic, antioxidant, anti-inflammatory and cardio-protective properties of spexin may contribute to its useful effects.

Key words: Spexin, Cardiometabolic changes, Obese type 2 diabetic rats, Metformin, Vildagliptin.

\section{INTRODUCTION}

Spexin is a peptide hormone that was intensely expressed in brain regions and peripheral tissues of human and rat, including the hypothalamus, cerebral cortex, pons, retina, esophagus, pancreas, stomach, heart, kidney, thyroid, liver, ovary, testis, adrenal glands and adipose tissue (Gu et al. 2015 and Liu et al. 2019).

Diabetes mellitus is a metabolic disorder that is caused by either lack of secretion of insulin or decreased sensitivity to insulin by the tissues (American Diabetes, 2010). It is one of the major health problems due to its micro and macrovascular hazards (Omar and Aboulkhair, 2017). Also, beta cells of islets of Langerhans and hence insulin secretion is markedly affected by diabetes mellitus (Nurdiana et al., 2017). Yu et al. (2012) declared that one of the most dangerous complications of diabetes is the diabetic cardiomyopathy.

Kolodziejski et al. (2018a) observed that circulating spexin levels were low in type 2 diabetes mellitus (T2DM) patients and inversely related to blood glucose and lipids. Also, Al-Daghri et al. (2018b) noted that spexin levels were significantly lower in obese children but without associations with markers of insulin resistance. Moreover, Ge et al. (2016) reported that spexin treatment in mice suppressed hepatic lipids and long-chain fatty acid uptake, contributing to loss in body weight.

Glucagon-like peptide-1 plays a climacteric role in secretion and signaling of insulin, and is degraded by dipeptidyl peptidase-IV (DPP-IV) (Silva Júnior et al., 2019). Lamers et al. (2011) noticed a rise in DPP-IV release in obese persons who had a higher risk of developing insulin resistance and diabetes (Almass et al., 2016). Also, Kirino et al. (2009) reported that plasma DPP-IV activity increased in rats after streptozotocin (STZ) injection and positively correlated with blood glucose levels. The DPP-IV inhibitor vildagliptin is an anti-hyperglycemic drug that may benefit patients with diabetes by regulating blood glucose levels, increasing weight loss and providing cardiovascular advantages with fewer associated adverse events ( $J i$ et al., 2016).

Metformin, an insulin sensitizer, is used for the treatment of T2DM as it decreased the elevated blood glucose level, reduced fat mass, decreased hepatic glucose production by suppressing gluconeogenesis and activating peripheral glucose utilization in muscle, intestine and liver (Mithieux et al., 2006). Some studies were published regarding the association between chronic hyperglycemia and cardiovascular complications in T2DM, including systemic hypertension and atherosclerosis (Boudina \& Abel, 2010; 


\section{EFFECT OF SPEXIN TREATMENT ON CARDIOMETABOLIC CHANGES... 737}

Rutter \& Nesto, 2011; Giorgino et al., 2013 and Wright et al., 2019).

Few studies were conducted to investigate the association between spexin and cardiometabolic changes with obesity complicated with diabetes and their results showed some controversies (Al-Daghri et al., $2018 a$ and Kumar et al., 2018).

Thus, this study was planned to explore the effect of spexin treatment on cardiometabolic changes (including also the histopathological and morphometric changes in heart and pancreas) in obese type 2 diabetic rats and the possible mechanisms involved.

\section{PATIENTS AND METHODS}

In Physiology Department, Zagazig Faculty of Medicine, this study was carried out during the period between August 2019 and November 2019. Thirty adult male albino rats of a local strain weighing 140-190 g, obtained from Animal House, Faculty of Medicine Zagazig University, housed in steel wire cages $(50 \times 30 \times 20 \mathrm{~cm}), 3$ rats/cage, in a light- and temperature-controlled room on normal light-dark cycle and fed a standard pellet lab chow with ad libitum access to tap water.

The experimental protocol in this study was conducted according to the data guiding the use of research animals and was approved by the Institutional Animal Care and Use Committee (IACUC), Zagazig University.

Experimental design: After acclimation period of 2 weeks, rats were divided randomly into 5 equal groups; control, diabetic, diabetic metformin treated, diabetic vildagliptin treated and diabetic spexin treated groups. In control group, rats were fed ordinary diet consisted of mixed rat laboratory chow (25.8\% protein, $62.8 \%$ carbohydrate and $11.4 \%$ fat) obtained from Faculty of Zagazig Agriculture and administered normal saline orally $1 \mathrm{ml} /$ day using oral gavage for 8 weeks (study period).

At the start of the 4th week, $0.01 \mathrm{M}$ citrate buffer, $\mathrm{pH} 4.5$ was injected intraperitoneally (i.p.) to mimic the STZ injections. In diabetic group, high fat diet (HFD), formed of protein $(16.45 \%)$, carbohydrate $(25.6 \%)$ and fat $(58.0 \%)$ in the form of cotton seed oil added to the laboratory chow diet (Cha et al., 2000), was fed to rats for 8 weeks. At the start of the 4th week, overnight fasted rats were injected with a single STZ injection (40 $\mathrm{mg} / \mathrm{kg}$ body weight, i.p., dissolved in $0.01 \mathrm{M}$ citrate buffer, $\mathrm{pH} 4.5$ ) to induce diabetes (Suman et al., 2016).

The animals were allowed to drink 5\% glucose solution overnight to overcome drug induced hypoglycemia. Blood glucose was estimated 7 days after STZ injection and rats with blood glucose $(>$ $200 \mathrm{mg} / \mathrm{dl}$ ) were considered diabetic (Rajesh et al., 2017). In diabetic metformin treated group, rats were managed as in diabetic group and in addition to that, metformin (obtained as Cidophage $500 \mathrm{mg}$ tabs, from CID, Egypt) was given orally $(300 \mathrm{mg} / \mathrm{kg} /$ day $)$ (Oliveira et al., 2014) by oral gavage to rats for 4 weeks from the start of 5th week to the end of 8 th week. 
KHALED ABD EL-FATTAH ABUL-FADLE et al.,

Table (1): Experimental design

\begin{tabular}{|c|c|c|c|c|c|}
\hline $\begin{array}{ll}\text { Parameter } & \text { Group } \\
\end{array}$ & Control & Diabetic & $\begin{array}{l}\text { Diabetic } \\
\text { metformin } \\
\text { treated }\end{array}$ & $\begin{array}{c}\text { Diabetic } \\
\text { vildagliptin } \\
\text { treated }\end{array}$ & $\begin{array}{l}\text { Diabetic } \\
\text { spexin } \\
\text { treated }\end{array}$ \\
\hline Duration (weeks) & 8 & 8 & 8 & 8 & 8 \\
\hline Number of rats & 6 & 6 & 6 & 6 & 6 \\
\hline Ordinary diet along the study & $\checkmark$ & & & & \\
\hline High fat diet along the study & & $\checkmark$ & $\checkmark$ & $\checkmark$ & $\checkmark$ \\
\hline $\begin{array}{l}\text { STZ i.p. at the start of the } 4^{\text {th }} \\
\text { week }\end{array}$ & & $\checkmark$ & $\checkmark$ & $\checkmark$ & $\checkmark$ \\
\hline $\begin{array}{l}\text { Metformin orally from the start } \\
\text { of the } 5^{\text {th }} \text { to the end of the } 8^{\text {th }} \\
\text { week of the study }\end{array}$ & & & $\checkmark$ & & \\
\hline $\begin{array}{l}\text { Vildagliptin orally from the start } \\
\text { of the } 5^{\text {th }} \text { to the end of the } 8^{\text {th }} \\
\text { week of the study }\end{array}$ & & & & $\checkmark$ & \\
\hline $\begin{array}{l}\text { Spexin i.p. from the start of the } \\
5^{\text {th }} \text { to the end of the } 8^{\text {th }} \text { week of } \\
\text { the study }\end{array}$ & & & & & $\checkmark$ \\
\hline
\end{tabular}

STZ, streptozotocin; i.p., intraperitoneal

In diabetic vildagliptin treated group, rats were manipulated as in diabetic group and in addition to that, vildagliptin (DPPIV inhibitor obtained as Gliptus $50 \mathrm{mg}$ tabs, from EVA Pharma, Egypt) was introduced orally (10 mg/kg/day) (Rajesh et al., 2017) using oral gavage to rats for 4 weeks from the start of 5th week to the end of 8th week. In diabetic spexin treated group, rats were managed as in diabetic group. In addition, spexin (purchased from Phoenix Pharmaceuticals; Belmont, CA, USA) was dissolved in normal saline and injected i.p. (35 $\mu \mathrm{g} / \mathrm{kg} /$ day) (Sassek et $a l ., 2018$ ) for 4 weeks from the start of 5 th week to the end of 8 th week.

Final body mass index (BMI) $(\mathrm{g} / \mathrm{cm} 2)$ was assessed in different studied groups by dividing final body weight (g) on Length2 $(\mathrm{cm} 2)$ where rat length was notified by estimating the distance between the anus and the nose (Novelli et al., 2007).
At the end of the experiment, the mean arterial blood pressure (MABP) was measured by the tail-cuff device (NARCO, Biosystem, Inc., Huston, Texas) after the rats have been warmed in a metabolic chamber for $30 \mathrm{~min}$ to be maintained at approximately $30 \mathrm{oC}$. The mean of the three consecutive measurements of MABP was considered as the pressure value for each rat (Sakamaki et al., 1987).

After measuring MABP, blood samples were collected from the tail vein (Suman et al., 2016) under ether anesthesia, left for $30 \mathrm{~min}$ at room temperature to clot and then centrifuged at $3000 \mathrm{rpm}$ for $15 \mathrm{~min}$ and serum was separated and stored at $80 \mathrm{oC}$ for estimation of biochemical parameters.

In the Biochemistry Laboratory, Zagazig Faculty of Medicine, serum was collected and used to estimate levels of spexin using commercial kits (catalog No. DEIA10757; Creative Diagnostics, USA). 
EFFECT OF SPEXIN TREATMENT ON CARDIOMETABOLIC CHANGES... 739

Also, serum levels of glucose, insulin, total cholesterol (TC), triglycerides (TG), high density lipoprotein (HDL), tumor necrosis factor alpha (TNF $\alpha$, interleukin 1 beta (IL-1 $\beta$, superoxide dismutase (SOD), malondialdehyde (MDA), lactate dehydrogenase (LDH), creatine kinasemyoglobin binding (CK-MB) and dipeptidyl peptidase-IV (DPP-IV) by kits (purchased from Sigma-Aldrich, USA) with catalog No. CBA086, RAB0904, MAK043, MAK266, MAK045, RAB0479, RAB0277, 19160, MAK085, MAK066, MAK116 and MAK088, respectively.

Both insulin resistance and $\beta$-cell function were calculated by homeostasis model assessment (HOMA):

Insulin resistance (HOMA-IR) = (Fasting glucose in $\mathrm{mg} / \mathrm{dl} \times$ Fasting insulin in $\mu I U / m l) / 405$ (Sun et al., 2007).

$\beta$ - Cell function $(\mathrm{HOMA}-\square)=(360 \mathrm{x}$ Fasting insulin in $\mu \mathrm{IU} / \mathrm{ml}) /($ Fasting glucose in mg/dl-63) (Hermans et al., 1999).

Atherogenic index was calculated from the following formula: Atherogenic index $(\mathrm{AI})=(\mathrm{TC}-\mathrm{HDL}) / \mathrm{HDL}$ (Kayamori and Igarashi, 1994).

LDL was estimated using the following formula: $\mathrm{LDL}(\mathrm{mg} / \mathrm{dl})=[\mathrm{TC}]-[(\mathrm{HDL})+$ (TG / 5)] (Friedewald et al., 1972).

Histopathological studies: After the animals were sacrificed at the end of the experiment, the heart and pancreas were fixed immediately in $10 \%$ buffered neutral formalin solution and embedded in paraffin to prepare paraffin sections of 5 $\mu \mathrm{m}$ thickness that were deparaffinized, rehydrated and stained with the following stains:
1. Hematoxylin and eosin stain: to visualize the microscopic architecture of the tissues under light microscope (Kiernan, 1999).

2. Mallory trichrome stain: to detect distribution of collagen fibres in pancreatic tissue (Bancroft \& Gamble, 2008).

3. Immunohistochemical localization of insulin: Sections from pancreatic specimens were selected for immunehistochemical study using the antiinsulin antibody; (Thermo Fisher Scientific, Fremont, CA, USA) that was prepared to detect the immunereaction of insulin. Hydrogen peroxide block was used for 15 minutes to decrease the background staining of endogenous peroxidase, then washing by phosphate buffer, later on incubation in the ultra $\mathrm{V}$ block for 5 minutes at room temperature. After that, sections were reared in the antiinsulin antibody after being diluted (1:200) for 30 minutes at room temperature. Then, light microscope was used to determine the immunohistochemical localization of insulin (Abdelrahim, 2013).

4. Immunohistochemical measurement of Bax expression and distribution: prepared cardiac muscle paraffin sections were treated according to the instructions of the staining kit, previously were treated with $3 \% \mathrm{H} 2 \mathrm{O} 2$ to neutralize endogenous peroxidase, then by serum blocking and heatinduced antigen recovery techniques. The specific primary antibody was added, and then sections were nursed overnight at $4 \mathrm{oC}$. Later, the secondary antibody was added with $30 \mathrm{~min}$ 
incubation period, then staining by $\mathrm{DAB}$ and hematoxylin counterstaining and observed under a microscope ( $\mathrm{Li}$ et al., 2018).

Morphometric study: The morphometric study was performed in Image Analyzing Unit of Human Anatomy and Embryology Department, Faculty of Medicine, Zagazig University, Egypt, using the computerized image analyzer (the Image $\mathbf{J}$ software plugin) to measure the followings:

1. Mean area percent of collagen in Mallory's trichrome-stained pancreatic specimens.

2. Mean area percent of insulin immuneexpression in islets of Langerhans in insulin immunostained sections (Abunasef et al., 2014 and Omar \& Aboulkhair, 2017).

3. Bax immunostained cardiac muscle area. Automatically by calibration, the image analyzer converts the measurement units (pixels) into micrometers. For each specimen, ten readings from non-overlapping fields were recorded, and the mean was calculated. The measured data were investigated at $400 \times$ magnification by the use of the interactive measurement menu.

\section{Statistical Analysis:}

The results were expressed as mean \pm standard deviation (SD). For statistical significance, one-way analysis of variance (ANOVA) and Tukey HSD for Post hoc multiple comparisons were used to compare means. The software, IBM Statistical Package for Social Sciences (SPSS) Version 26 Software for Windows (SPSS, Inc., Chicago, IL, USA), was used for that purpose.

Also, Graph Pad Prism (Version 8 Software for Windows) was used to analyze the Pearson's correlation coefficient between serum levels of spexin and some studied parameters within the diabetic group. Significance was considered with $\mathrm{P}$ value $\leq 0.05$.

\section{RESULTS}

Cardiometabolic changes in diabetic group (Table-2): There was a significant increase in final BMI, serum glucose, serum insulin, HOMA-IR, serum TC, serum TG, serum LDL, atherogenic index, serum DPP-IV, serum TNF $\alpha$, serum IL$1 \beta$, serum MDA, serum LDH, serum CK$\mathrm{MB}$ and MABP, with a significant decrease in HOMA- $\beta$, serum HDL, serum SOD and serum spexin in comparison to that in the control group.

Cardiometabolic changes in diabetic metformin treated group (Table-2): A significant decrease was found in final
BMI, serum glucose, serum insulin, HOMA-IR, serum TC, serum TG, serum LDL, atherogenic index, serum DPP-IV, serum TNF $\alpha$, serum IL-1 $\beta$, serum MDA, serum LDH, serum CK-MB and MABP, with a significant increase in HOMA- $\beta$, serum HDL, serum SOD and serum spexin in comparison to that in the diabetic group.

Cardiometabolic changes in diabetic vildagliptin treated group (Table-2): There was a significant decrease in final BMI, serum glucose, serum insulin, HOMA-IR, serum TC, serum TG, serum 


\section{EFFECT OF SPEXIN TREATMENT ON CARDIOMETABOLIC CHANGES... 741}

LDL, atherogenic index, serum DPP-IV, serum TNF $\alpha$, serum IL-1 $\beta$, serum MDA, serum $\mathrm{LDH}$, serum CK-MB and MABP, with a significant increase in HOMA- $\beta$, serum HDL, serum SOD and serum spexin in comparison to that in the diabetic group.

Cardiometabolic changes in diabetic spexin treated group (Table-2): A significant decrease was noticed in final BMI, serum glucose, serum insulin, HOMA-IR, serum TC, serum TG, serum LDL, atherogenic index, serum DPP-IV, serum TNF $\alpha$, serum IL-1 $\beta$, serum MDA, serum $\mathrm{LDH}$, serum CK-MB and MABP, with a significant increase in HOMA- $\beta$, serum HDL, serum SOD and serum spexin in comparison to that in the diabetic group.

Correlation between serum spexin level and some studied parameters within the diabetic group (Table-3): Spexin serum level was negatively correlated with each of BMI, serum glucose, HOMA-IR, serum TC, serum DPP-IV, atherogenic index, serum TNF $\alpha$, serum LDH and serum CK-MB, but it was positively associated with both HOMA- $\beta$ and serum SOD.

Table (2): Biochemical changes in different studied groups (number of rats in each group $=6$ )

\begin{tabular}{|c|c|c|c|c|c|}
\hline Parameters & Control & Diabetic & $\begin{array}{c}\text { Diabetic } \\
\text { metformin } \\
\text { treated }\end{array}$ & $\begin{array}{c}\text { Diabetic } \\
\text { vildagliptin } \\
\text { treated } \\
\end{array}$ & $\begin{array}{c}\text { Diabetic spexin } \\
\text { treated }\end{array}$ \\
\hline $\begin{array}{l}\begin{array}{l}\text { Final BMI } \\
\left(\mathrm{g} / \mathrm{cm}^{2}\right)\end{array} \\
\end{array}$ & $0.57 \pm 0.04$ & $0.82 \pm 0.02^{\mathrm{a}}$ & $0.66 \pm 0.03^{a \& b}$ & $0.69 \pm 0.05^{a \& b}$ & $0.71 \pm 0.03^{a \& b}$ \\
\hline $\begin{array}{l}\text { Serum glucose } \\
(\mathrm{mg} / \mathrm{dl})\end{array}$ & $80.17 \pm 1.33$ & $363.83 \pm 6.68^{a}$ & $166 \pm 6.16^{a \& b}$ & $162.17 \pm 6.08^{a \& b}$ & $169.5 \pm 8.92^{\mathrm{a} \& \mathrm{~b}}$ \\
\hline $\begin{array}{l}\text { Serum insulin } \\
(\mu \mathrm{IU} / \mathrm{ml})\end{array}$ & $8.58 \pm 0.5$ & $30.12 \pm 2.89^{a}$ & $15.37 \pm 1.14^{\mathrm{a} \& \mathrm{~b}}$ & $17.33 \pm 1.14^{\mathrm{a} \& \mathrm{~b}}$ & $15.99 \pm 0.64^{\mathrm{a} \& \mathrm{~b}}$ \\
\hline HOMA-IR & $1.7 \pm 0.12$ & $27.09 \pm 2.98^{a}$ & $6.3 \pm 0.53^{\mathrm{a} \& b}$ & $6.94 \pm 0.56^{a \& b}$ & $6.69 \pm 0.35^{a \& b}$ \\
\hline НОМА- $\beta$ & $180.5 \pm 11.1$ & $36.01 \pm 2.91^{\mathrm{a}}$ & $53.88 \pm 4.98^{a \& b}$ & $63.08 \pm 4.98^{a \& b}$ & $54.43 \pm 5.98^{a \& b}$ \\
\hline $\begin{array}{l}\text { Serum TC } \\
(\mathrm{mg} / \mathrm{dl})\end{array}$ & $70 \pm 5.1$ & $287.67 \pm 9.73^{a}$ & $116 \pm 4.15^{a \& b}$ & $107.83 \pm 3.49^{a \& b}$ & $107.83 \pm 6.34^{a \& b}$ \\
\hline $\begin{array}{l}\text { Serum TG } \\
(\mathrm{mg} / \mathrm{dl})\end{array}$ & $77 \pm 6.1$ & $315.33 \pm 10.76^{a}$ & $138.83 \pm 7.19^{\mathrm{a} \& \mathrm{~b}}$ & $135.17 \pm 7.17^{\mathrm{a} \& \mathrm{~b}}$ & $133 \pm 7.4^{\mathrm{a} \& \mathrm{~b}}$ \\
\hline $\begin{array}{l}\text { Serum HDL } \\
(\mathrm{mg} / \mathrm{dl})\end{array}$ & $38.67 \pm 4.55$ & $20 \pm 2.28^{a}$ & $30.67 \pm 2.42^{\mathrm{a} \& \mathrm{~b}}$ & $30 \pm 2.61^{a \& b}$ & $28.33 \pm 3.33^{a \& b}$ \\
\hline $\begin{array}{l}\text { Serum LDL } \\
(\mathrm{mg} / \mathrm{dl})\end{array}$ & $15.93 \pm 1.38$ & $204.6 \pm 10.62^{a}$ & $57.57 \pm 3.17^{a \& b}$ & $50.8 \pm 5.53^{a \& b}$ & $52.9 \pm 4.29^{\mathrm{a} \& b}$ \\
\hline $\begin{array}{l}\text { Atherogenic } \\
\text { index }\end{array}$ & $0.82 \pm 0.09$ & $13.56 \pm 1.84^{\mathrm{a}}$ & $2.8 \pm 0.28^{a \& b}$ & $2.62 \pm 0.36^{\mathrm{a} \& \mathrm{~b}}$ & $2.84 \pm 0.33^{a \& b}$ \\
\hline $\begin{array}{l}\text { Serum DPP-IV } \\
\text { (microunit/ml) }\end{array}$ & $4.9 \pm 0.15$ & $41.53 \pm 1.57^{a}$ & $27.4 \pm 1.75^{a \& b}$ & $13.64 \pm 1.02^{\mathrm{a}, \mathrm{b} \& \mathrm{c}}$ & $19.37 \pm 0.59^{\mathrm{a}, \mathrm{b}, \mathrm{c} \& d}$ \\
\hline $\begin{array}{l}\text { Serum TNF } \alpha \\
(\mathrm{pg} / \mathrm{ml})\end{array}$ & $23.65 \pm 0.73$ & $93.59 \pm 1.74^{a}$ & $41.5 \pm 0.62^{\mathrm{a} \& \mathrm{~b}}$ & $45.13 \pm 1.12^{\mathrm{a}, \mathrm{b} \& \mathrm{c}}$ & $42.92 \pm 1.26^{\mathrm{a}, \mathrm{b} \& \mathrm{~d}}$ \\
\hline $\begin{array}{l}\text { Serum IL-1 } \beta \\
(\mathrm{pg} / \mathrm{ml})\end{array}$ & $36.36 \pm 0.6$ & $60.28 \pm 0.66^{\mathrm{a}}$ & $47.31 \pm 0.51^{\mathrm{a} \& \mathrm{~b}}$ & $48.86 \pm 1.01^{\mathrm{a}, \mathrm{b} \& \mathrm{c}}$ & $50.53 \pm 1.34^{\mathrm{a}, \mathrm{b}, \mathrm{c} \& d}$ \\
\hline $\begin{array}{l}\text { Serum SOD } \\
\text { (Unit/ml) }\end{array}$ & $354.99 \pm 4.8$ & $169.75 \pm 1.35^{\mathrm{a}}$ & $296.57 \pm 4.11^{\mathrm{a} \& \mathrm{~b}}$ & $287.19 \pm 2.95^{\mathrm{a}, \mathrm{b} \& \mathrm{c}}$ & $298.63 \pm 5.77^{\mathrm{a}, \mathrm{b} \& d}$ \\
\hline $\begin{array}{l}\text { Serum MDA } \\
(\mathbf{n m o l} / \mathbf{m l})\end{array}$ & $11.36 \pm 0.32$ & $22.56 \pm 0.43^{a}$ & $15.5 \pm 0.41^{\mathrm{a} \& \mathrm{~b}}$ & $14.84 \pm 0.2^{\mathrm{a}, \mathrm{b} \& \mathrm{c}}$ & $15.26 \pm 0.3^{a \& b}$ \\
\hline $\begin{array}{l}\text { Serum spexin } \\
(\mathrm{ng} / \mathrm{ml})\end{array}$ & $1.78 \pm 0.06$ & $0.73 \pm 0.05^{a}$ & $1.24 \pm 0.04^{a \& b}$ & $1.18 \pm 0.02^{\mathrm{a} \& b}$ & $1.79 \pm 0.03^{b, c \& d}$ \\
\hline $\begin{array}{l}\text { Serum LDH } \\
(\mathbf{U} / \mathbf{L})\end{array}$ & $256.83 \pm 7.74$ & $522.15 \pm 5.65^{\mathrm{a}}$ & $418 \pm 4.24^{\mathrm{a} \& \mathrm{~b}}$ & $392.1 \pm 6.84^{\mathrm{a}, \mathrm{b} \& \mathrm{c}}$ & $398.63 \pm 7.17^{\mathrm{a}, \mathrm{b} \& \mathrm{c}}$ \\
\hline $\begin{array}{l}\text { Serum CK-MB } \\
\text { (U/L) }\end{array}$ & $133.12 \pm 5.43$ & $264.12 \pm 3.98^{\mathrm{a}}$ & $200.63 \pm 3.6^{a \& b}$ & $189.35 \pm 2.71^{\mathrm{a}, \mathrm{b} \& \mathrm{c}}$ & $193.97 \pm 2.24^{\mathrm{a}, \mathrm{b} \& \mathrm{c}}$ \\
\hline $\begin{array}{l}\text { MABP } \\
(\mathbf{m m H g})\end{array}$ & $117.5 \pm 2.74$ & $138.83 \pm 2.64^{a}$ & $118.33 \pm 2.16^{b}$ & $119.33 \pm 2.16^{b}$ & $118.5 \pm 1.87^{b}$ \\
\hline
\end{tabular}

Data were expressed as mean \pm SD. ${ }^{\mathrm{P}}<0.05$ when compared with control group. ${ }^{\mathrm{b}} \mathrm{P}<0.05$ when compared with diabetic group. ${ }^{c} \mathrm{P}<0.05$ when compared with diabetic metformin treated group. ${ }^{\mathrm{d}} \mathrm{P}<0.05$ when compared with diabetic 
vildagliptin treated group. BMI, body mass index; HOMA-IR, homeostasis model assessment insulin resistance; HOMA- $\beta$, homeostasis model assessment $\beta$-cell function; TC, total cholesterol; TG, triglycerides; HDL, high density lipoprotein; LDL, low density lipoprotein; DPP-IV, Dipeptidyl peptidase-IV; TNF $\alpha$, tumor necrosis factor alpha; IL$1 \beta$, interleukin-1 beta; SOD, superoxide dismutase; MDA, malondialdehyde; LDH, lactate dehydrogenase; CK-MB, creatine kinase-myoglobin binding; MABP, mean arterial blood pressure.

Table (3): Pearson's correlation coefficient (r) between serum spexin level and some studied parameters within the diabetic group (number of rats $=6$ )

\begin{tabular}{|c|c|c|c|c|c|c|c|c|c|c|c|c|}
\hline Corr & Parameters & 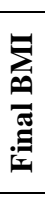 & 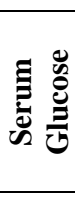 & $\begin{array}{l}3 \\
\vdots \\
\vdots \\
\vdots\end{array}$ & 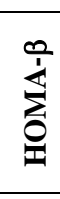 & & 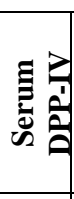 & 鄢 & 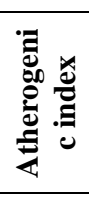 & 焉 & 田 & 光 \\
\hline \multirow{2}{*}{ 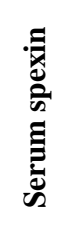 } & $\mathbf{r}$ & $\begin{array}{l}\stackrel{0}{\circ} \\
\stackrel{0}{\oplus}\end{array}$ & ڤั. & $\begin{array}{l}\text { fे } \\
\text { î. }\end{array}$ & ลิ & 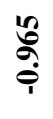 & $\begin{array}{l}\underset{J}{J} \\
\stackrel{0}{0} \\
\stackrel{i}{0}\end{array}$ & $\begin{array}{l}\stackrel{0}{\circ} \\
\stackrel{0}{0} \\
\Theta\end{array}$ & 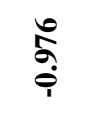 & $\frac{m}{9}$ & $\begin{array}{l}\vec{\sigma} \\
\bar{\varphi}\end{array}$ & $\hat{\hat{\varphi}}$ \\
\hline & $P$ Value & 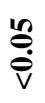 & $\begin{array}{l}\overline{\dot{\theta}} \\
\dot{\hat{v}}\end{array}$ & $\begin{array}{l}\overline{\tilde{\theta}} \\
\hat{\vec{v}}\end{array}$ & $\begin{array}{l}\overline{\tilde{\theta}} \\
\stackrel{\vec{v}}{\mathrm{v}}\end{array}$ & $\begin{array}{l}\overrightarrow{\dot{\theta}} \\
\dot{\vec{v}}\end{array}$ & $\begin{array}{l}\stackrel{n}{\dot{\theta}} \\
\hat{\vec{v}}\end{array}$ & 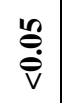 & $\begin{array}{l}\overline{\tilde{\theta}} \\
\stackrel{\dot{v}}{v}\end{array}$ & 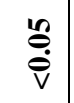 & 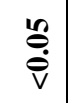 & $\begin{array}{l}\vec{\nabla} \\
\dot{\nabla}\end{array}$ \\
\hline
\end{tabular}

BMI, body mass index; HOMA-IR, homeostasis model assessment insulin resistance; HOMA- $\beta$, homeostasis model assessment $\beta$-cell function; TC, total cholesterol; DPP-IV, Dipeptidyl peptidase-IV; TNF $\alpha$, tumor necrosis factor alpha; SOD, superoxide dismutase; LDH, lactate dehydrogenase; CK-MB, creatine kinase-myoglobin binding.

\section{Histopathological results:}

Hematoxylin and eosin (H\&E) stained pancreatic sections: The control group showed normal histological structure, with presence of lobules, formed of adherent acini. The acini are formed of pyramidal shaped cells with apical acidophilic cytoplasm and basal basophilic nuclei. The islets of Langerhans appeared as pale regular oval areas with blood capillaries present in between the cellular groups in addition to big number of $\beta$ - cells with distinctive round nuclei (Fig.1A).

But diabetic group showed pathological variations of both exocrine and endocrine pancreatic components, where the acini were irregularly organized, widely separated with presence of inflammatory cell infiltrations. The acinar cells appeared swollen with cytoplasmic vacuoles and dark stained nuclei, dilated ducts with presence of congested blood vessels. Islets of Langerhans appeared disturbed with irregular outline, and even lost, with vacuolations in between the cells of islet (Fig.1B\&1B*). Diabetic metformin treated rats showed regeneration of the islet cells with nearly regular outline and slight normal appearance of most cells (Fig.1C).

Diabetic vildagliptin treated rats showed approximately normal organization and restoration of the islets' size, also the exocrine part showed decrease in vacuoles and trophic changes (Fig.1D). In diabetic spexin treated rats, a picture nearly similar to that of control group, with restoration of the borders between the exocrine and the endocrine pancreatic parts (Fig.1E).

\section{Mallory's trichrome-stained} pancreatic sections: The control group showed delicate collagen fibers inbetween the pancreatic acini, around the blood vessels and the interlobular duct (Fig.2A). In diabetic group, there was an apparent increase in collagen fibers around the dilated ducts, congested blood vessels and within the islet (Fig.2B\&2B*), while in metformin treated diabetic group (Fig.2C\&2C*) and vildagliptin treated diabetic group (Fig.2D) there was apparent decrease in amount of collagen fibers around the apparently dilated ducts. Spexin treated 


\section{EFFECT OF SPEXIN TREATMENT ON CARDIOMETABOLIC CHANGES...}

diabetic group showed minimal amount of collagen fibers around the interlobar ducts and in-between acini (Fig.2E $\left.\& 2 \mathrm{E}^{*}\right)$.

\section{Anti-insulin} pancreatic cytoplasmic staining of the islets of Langerhans in control group was detected in all cells especially in the center and appeared dense brown in color (Fig.3A). In diabetic group there was marked decrease in immunereaction with presence of vacuolations (Fig.3B). In diabetic metformin treated, diabetic vildagliptin treated and diabetic spexin treated groups, apparent increase in immune-reaction of the cells was observed as compared with the diabetic group (Fig. 3C, 3D\&3E).
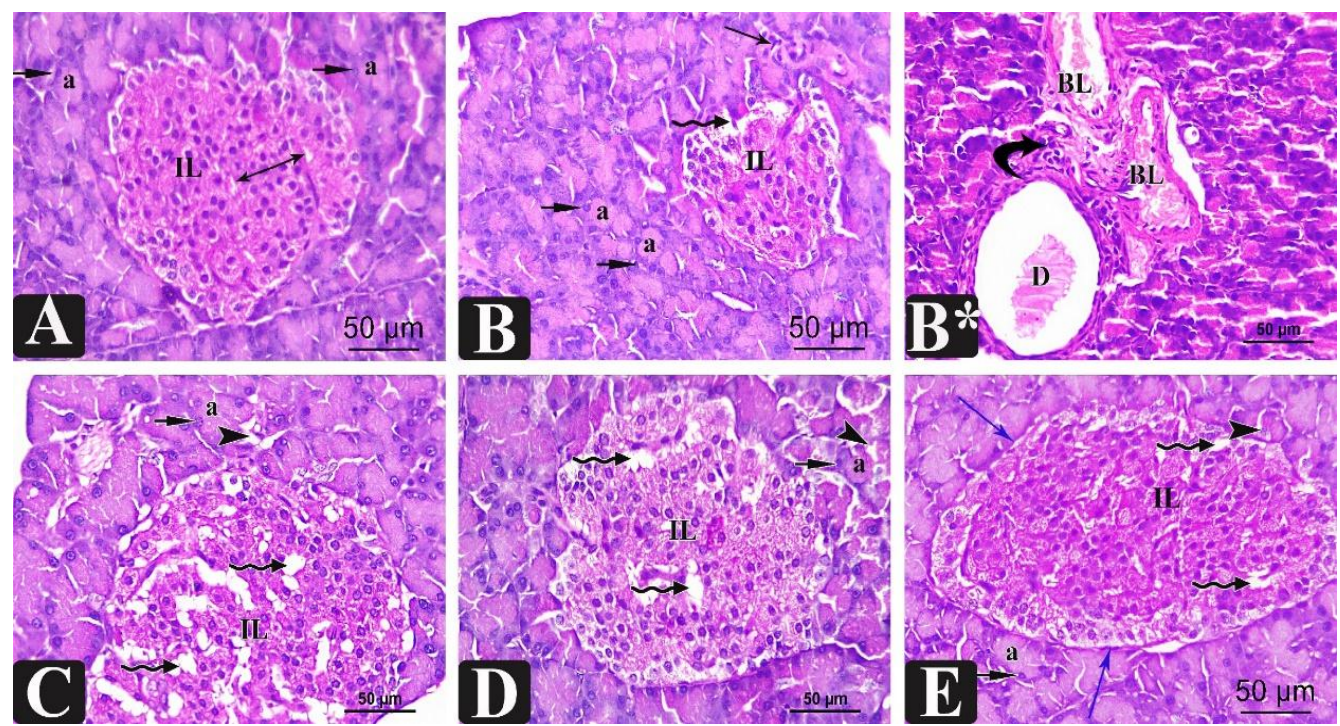

Fig. (1): Photomicrographs of pancreatic sections. A. Control group displaying normal pancreatic histological structure with exocrine and endocrine parts. Tightly packed acini (a) arranged into small lobules, with acidophilic cytoplasm and basal basophilic nuclei (arrow). The islet cells (IL) are seen intermingled with the acinar cells and are lightly stained with capillaries in between (double headed arrow). B.\&B*. Diabetic group revealed abnormal shape of both the exocrine and endocrine pancreatic parts. The acinar cells are puffy with small vacuoles (arrow head) and some with dark stained nuclei (long arrow). Apparently dilated duct (D) and congested dilated blood vessels (BL) with inflammatory infiltration (curved arrow). The islet cells (IL) are disturbed with dark stained nuclei and multiple vacuoles (zigzag arrow). Interlobular ducts were slightly dilated and lined with flattened epithelium (red arrow). C. Diabetic rats treated with metformin showing slight alteration of the pancreatic structure, the acini showed cytoplasmic vacuolations (arrow head). D. Diabetic rats treated with vildagliptin showing approximately normal organization of islets of Langerhans (IL) with decreased vacuoles (zigzag arrow), trophic changes of the exocrine part were less severe with basophilic nuclei (arrow) of the acini (a) and decreased vacuoles (arrow head). E. Diabetic rats treated with spexin showed apparent restoration of histological structure of the islets (IL), decreased the vacuolations within the islets of Langerhans (zigzag arrow) and in the acinar cells (arrow head), restoration of the borders between the exocrine and the endocrine pancreatic parts (blue arrows). (H\&E X400)

Hematoxylin and eosin stained cardiac sections: Cardiac muscle in control group showed normal histological pattern with regular arrangement of muscle fibers and normal cardiac vasculature with clear eosinophilic cytoplasm and flattened centrally located ellipsoid nuclei. The fibers were connected by intercalated discs. Flat dark nuclei of the fibroblasts in the endomysium were detected (Fig.4A).

In the diabetic group the muscle fibers were irregularly arranged and the striations were lost with highly widened endomysium. Degeneration of the 
KHALED ABD EL-FATTAH ABUL-FADLE et al.,

cardiac myocytes with fragmentations of some and presence of inflammatory cell infiltration were noted. The nuclei looked faintly stained and others are pyknotic or karyolytic (Fig.4B\&4B*). In diabetic metformin treated, diabetic vildagliptin treated and diabetic spexin treated groups there was an apparent restoration of the normal structure of the cardiac muscle fibers with slight widening between the muscle fibers (Fig.4C, 4D\&4E).

Immunohistochemical staining of the cardiac muscle: Bax expression technique displayed an apparent increase of the brown color in diabetic group as compared to the other groups (Fig.5B), while in diabetic metformin treated, diabetic vildagliptin treated and diabetic spexin treated groups, there was an apparent decrease in Bax expression as compared to the diabetic group (Fig. 5C, 5D\&5E).

Morphometric results (Table-4):

Mean area percent of collagen in pancreatic tissue, presented a statistically significant increase in diabetic, diabetic metformin treated, diabetic vildagliptin treated and diabetic spexin treated groups versus to the control group, with a statistically significant decrease in diabetic metformin treated, diabetic vildagliptin treated and diabetic spexin treated groups as compared to the diabetic group. But no statistically significant difference was detected between diabetic metformin treated, diabetic vildagliptin treated and diabetic spexin treated groups.

Mean area percent of insulin immune-reactivity in diabetic, diabetic metformin treated, diabetic vildagliptin treated and diabetic spexin treated groups showed a significant decrease in mean area percent of insulin as compared to the control group,

while in diabetic metformin treated, diabetic vildagliptin treated and diabetic spexin treated groups it revealed a significant increase as compared to diabetic group. However, no statistically significant difference was detected between diabetic metformin treated, diabetic vildagliptin treated and diabetic spexin treated groups.

Bax expression showed a significant increase in diabetic, diabetic metformin treated, diabetic vildagliptin treated and diabetic spexin treated groups as compared control group. Also, diabetic metformin treated, diabetic vildagliptin treated and diabetic spexin treated groups were presented with a significant decrease in Bax expression as compared to diabetic group. In addition, no statistically significant difference was detected between diabetic metformin treated, diabetic vildagliptin treated and diabetic spexin treated groups. 


\section{EFFECT OF SPEXIN TREATMENT ON CARDIOMETABOLIC CHANGES... 745}
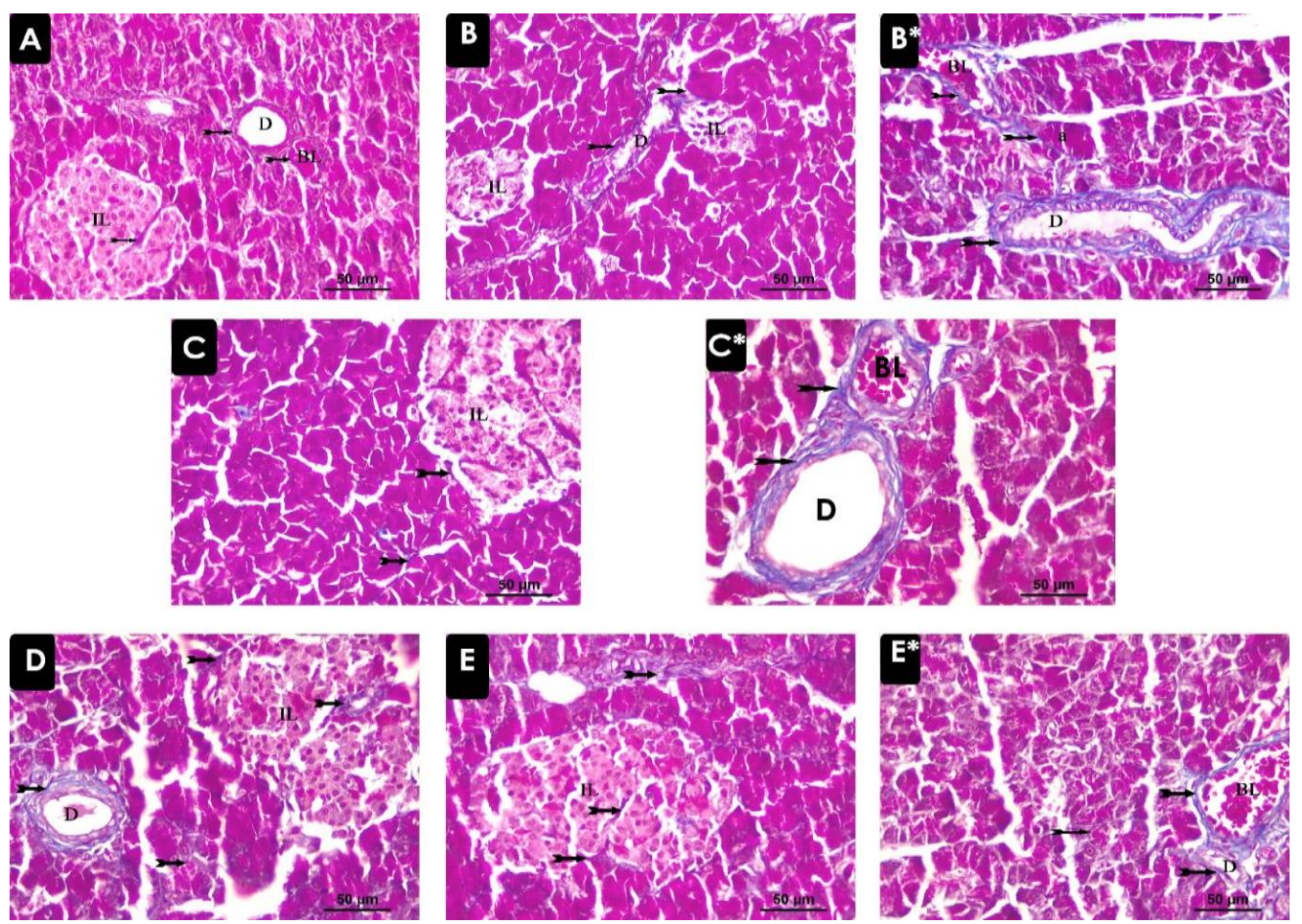

Fig. (2): Mallory's trichrome stained pancreatic sections. A. control group showed delicate collagen fibers in-between the pancreatic acini (tailed arrow), around the blood vessels (BL) and the interlobular duct (D). B.\& $\mathbf{B}^{*}$. diabetic group showed an apparent increase in collagen fibers around the dilated ducts (D), congested blood vessels (BL) and within the islet (IL) (tailed arrow). C.\&C*. metformin treated diabetic group and D. vildagliptin treated diabetic group showed apparent decrease in amount of collagen fibers. E.\&E* Spexin treated diabetic group showed minimal amount of collagen fibers around the interlobar ducts (D), in-between acini (tailed arrow). (Mallory's Trichrome X400).

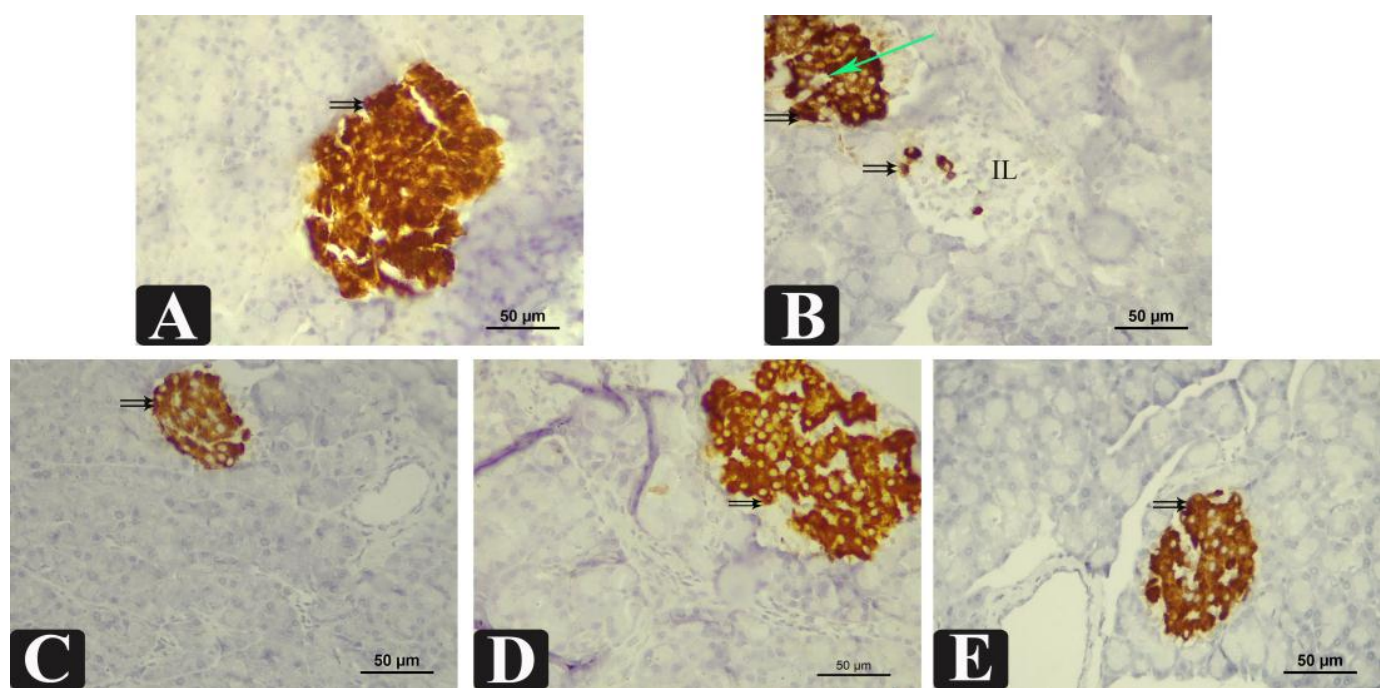

Fig. (3): Photomicrographs of pancreatic specimens immune-stained with (Anti-insulin Immunostaining X400). A. control group showed strong positive immunoreaction (dark brown color) (double arrow) mainly in the center of the islets (B-cells). B. diabetic group displaying noticeable decrease in the immunoreaction with irregular outline of the islets and apparent decrease in the area of islets with presence of vacuoles (green arrow). C. metformin treated diabetic group and $\mathbf{D}$. vildagliptin treated diabetic group showed apparent increase in area of islets as compared with diabetic group. E. spexin treated diabetic group showed an obvious increase in beta-cells immunoreaction as compared with diabetic group. 

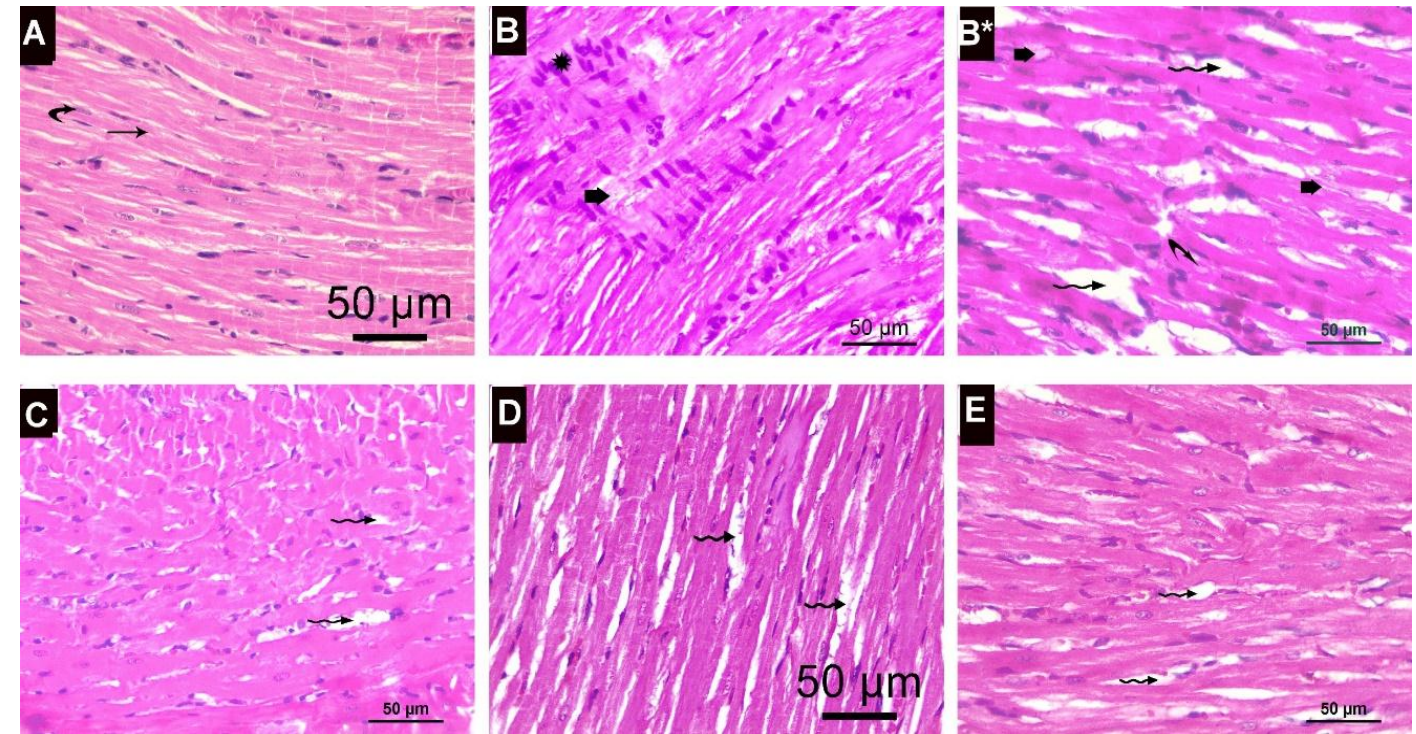

Fig. (4): Photomicrograph displaying section of cardiac muscle. A. control group cardiac muscle fibers were regular (arrow) with flattened nucleus (curved arrow). B.\&B* diabetic group cardiac muscle fibers were irregular, widely separated (zigzag arrow) and showed myolysis (thick arrow), with presence of inflammatory cell infiltrate $*^{*}$ ), the nucleus showed karyolysis (curved arrow). C. metformin treated diabetic, D. vildagliptin treated diabetic group and $\mathbf{E}$. spexin treated diabetic group showed apparent improvement of the histological changes found in the diabetic group with decreased separation between cardiac muscle fibers (zigzag arrow). (H\&E X400)

\section{DISCUSSION}

To declare the effect of spexin treatment on cardiometabolic changes occurred in type 2 diabetes mellitus and the possible mechanisms involved, a rat model of high fat diet- and a low dose streptozotocin induced diabetes was used in this study. The results of this study confirmed occurrence of cardiometabolic changes in obese type 2 diabetic rats which were ameliorated with treatment by spexin as well as by the standard drugs (metformin and vildagliptin). 


\section{EFFECT OF SPEXIN TREATMENT ON CARDIOMETABOLIC CHANGES... 747}

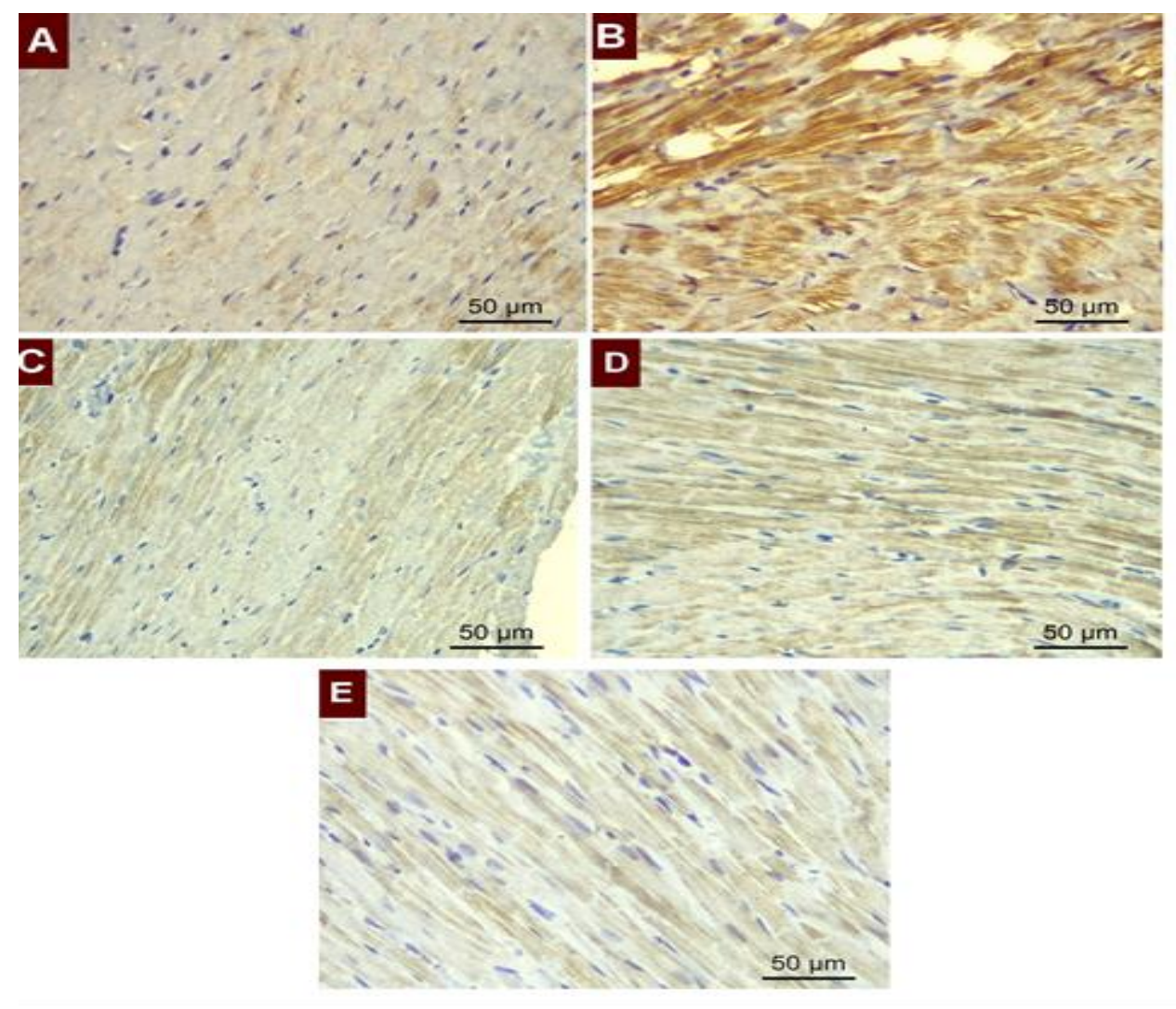

Fig. (5): Photomicrographs of cardiac specimens immune-stained with Bax expression (X400). A. control group showed minimal Bax expression B. diabetic group showed enhanced Bax expression C. diabetic rats treated with metformin, D. diabetic rats treated with vildagliptin group and E. diabetic rats treated with spexin showed apparent decrease in Bax expression as compared to the diabetic group.

Table (4): The mean area percent (Area \%) of (collagen in pancreatic tissue, insulin immune-reactivity and Bax expression) in the different groups. Data were expressed as mean \pm SD. Number of rats in each group $=6$.

\begin{tabular}{|c|c|c|c|c|c|}
\hline Variables & Control & Diabetic & $\begin{array}{c}\text { Diabetic } \\
\text { metformin } \\
\text { treated }\end{array}$ & $\begin{array}{c}\text { Diabetic } \\
\text { vildagliptin } \\
\text { treated }\end{array}$ & $\begin{array}{c}\text { Diabetic spexin } \\
\text { treated }\end{array}$ \\
\hline $\begin{array}{l}\text { Area \% of } \\
\text { collagen }\end{array}$ & $15.66 \pm 1.71$ & $\begin{array}{c}\mathbf{3 9 . 2 1} \pm \mathbf{1 . 8 3} \\
{ }^{\mathrm{a} P}<0.001\end{array}$ & $\begin{array}{c}\mathbf{2 0 . 5 6} \pm \mathbf{1 . 8 4} \mathbf{4}^{\mathrm{a} \& \mathbf{b}} \\
{ }^{\mathrm{a}} \mathrm{P}<0.01 \\
{ }^{\mathrm{b}} \mathrm{P}<0.001\end{array}$ & 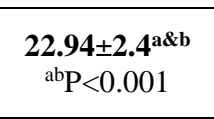 & $\begin{array}{c}\mathbf{2 0 . 7} \pm \mathbf{2 . 2 3} \text { a\&b } \\
{ }^{\mathrm{a}} \mathrm{P}<0.01 \\
{ }^{\mathrm{b}} \mathrm{P}<0.001 \\
\end{array}$ \\
\hline $\begin{array}{l}\text { Area \% of } \\
\text { insulin } \\
\text { immune- } \\
\text { reactivity }\end{array}$ & $13.26 \pm 1.08$ & $\begin{array}{c}\mathbf{2 . 0 3} \pm \mathbf{0 . 4 2} \\
{ }^{\mathrm{a}} \mathrm{P}<0.001\end{array}$ & $\begin{array}{c}\mathbf{9 . 2 0} \pm \mathbf{1 . 1 6}^{\mathrm{a} \& \mathrm{~b}} \\
\mathrm{a}, \mathrm{b} \mathrm{P}<0.001\end{array}$ & $\begin{array}{c}10.03 \pm \mathbf{1 . 5 6}^{\mathrm{a} \& b} \\
{ }^{\mathrm{a}, \mathrm{b}} \mathrm{P}<0.001\end{array}$ & $\begin{array}{c}\mathbf{1 0 . 1 8} \pm \mathbf{1 . 2 3}^{\mathrm{a} \& \mathrm{~b}} \\
{ }^{\mathrm{a}, \mathrm{b}} \mathrm{P}<0.001\end{array}$ \\
\hline $\begin{array}{l}\text { Area \% Bax } \\
\text { expression }\end{array}$ & $23.33 \pm 1.08$ & $\begin{array}{c}\mathbf{6 8 . 2 4} \pm \mathbf{5 . 4}^{\mathbf{a}} \\
\text { a }<<0.001\end{array}$ & $\begin{array}{c}\mathbf{3 9 . 6 0} \pm \mathbf{1 . 7}^{\mathbf{a} \& \mathbf{b}} \\
\text { a,b } \mathrm{P}<0.001\end{array}$ & $\begin{array}{c}\mathbf{4 1 . 2 8} \pm \mathbf{2 . 2 4} \\
\mathrm{a}, \mathrm{b} \mathrm{P}<0.001\end{array}$ & $\begin{array}{c}\text { 37.68.9 } \pm 1.95^{\text {a\&b }} \\
\text { a,b } P<0.001\end{array}$ \\
\hline
\end{tabular}

In the diabetic group, significant cardiometabolic changes were noticed, in comparison with the control group, in the form of disturbed, glucose homeostasis (hyperglycemia, hyperinsulinemia, insulin resistance and decreased beta cell function), lipid profile (increased serum level of TC, TG and LDL and increased 
atherogenic index, with decreased serum level of HDL) and cardiac function (increased serum level of both $\mathrm{LDH}$ and CK-MB with increased MABP).

These results were supported by Rajesh et al. (2017) who confirmed presence of hyperglycemia, insulin resistance and decreased pancreatic beta cell function in obese rats. Also, Al-Daghri et al. (2018a) stated that elevation in serum CK-MB, a cardiac enzyme, reflected the extent of cardiac damage. The current changes could be explained according to the results of this study by presence of obesity (evidenced by the significant increase in final BMI) which was considered as one of the risk factors of insulin resistance as discussed by Almass et al. (2016) and Kolodziejski et al. (2018a). Also, other mechanisms that could explain cardiometabolic disturbances in obese diabetic rats as declared by the present study included the significant increase in serum levels of proinflammatory cytokines (TNF $\alpha$ and IL-1 $\beta$ ), increased oxidative stress (decreased serum level of SOD with increased serum level of MDA), and increased activity of DPP-IV which degraded glucagon-like peptide-1 that affected glucose homeostasis as stated by Silva Júnior et al. (2019).

These results were in agreement with Wright et al. (2019) who stated that oxidative stress was associated with overproduction of reactive oxygen species and played a vital role in the development of complications of diabetes. Also, Lamers et al. (2011) reported a rise in DPP-IV release in obese individuals who had an increased risk of having insulin resistance and diabetes. In addition, Kirino et al. (2009) found an increase in plasma DPP-IV activity in rats after streptozotocin injection. Moreover, the current study declared that the decrease in serum spexin level in obese type 2 diabetic rats could be considered as another mechanism that could explain the cardiometabolic changes occurred with type 2 diabetes as spexin serum level was decreased significantly and was negatively associated with each of final BMI, serum glucose, HOMA-IR, serum TC, serum DPP-IV, atherogenic index, serum TNF $\alpha$, serum LDH and serum CK-MB, but it was positively associated with both HOMA- $\beta$ and serum SOD.

This was supported by Walewski et al. (2014), Kolodziejski et al. (2018a) and AlDaghri et al. (2018b) who explored a decrease in serum spexin in patients with metabolic syndrome and in obese adults. Also, Walewski et al. (2010) declared that the gene encoding spexin (Cg12orf39) was the most downregulated gene in fat tissue in humans with obesity. In addition, Gu et al. (2015) reported an inverse correlation between serum levels of both spexin and glucose in adults with type 2 diabetes mellitus.

In addition, Lin et al. (2018) found a negative correlation between serum levels of both spexin and total cholesterol. Moreover, Kumar et al. (2016) stated that in obese children, spexin was negatively correlated with body weight. Thus, to confirm the role of spexin in the pathogenesis of cardiometabolic changes found with diabetes, it was evaluated for efficacy in treatment of type 2 diabetes in comparison with the standard drugs (metformin and vildagliptin).

The previously mentioned cardiometabolic disturbances of type 2 
EFFECT OF SPEXIN TREATMENT ON CARDIOMETABOLIC CHANGES... 749

diabetes mellitus explained the histopathological and inflammatory changes in the diabetic cardiac muscle detected in this study. The muscle fibers were irregularly arranged with loss of striations and widened endomysium, in hematoxylin and eosin stained sections of the cardiac muscle of diabetic group. In addition, degenerative changes of the cardiac myocytes and fragmentations of some with presence of inflammatory cell infiltrate were also detected. The nuclei looked faintly stained while, others were pyknotic or karyolytic. These findings are similar to those of Thent et al. (2012), Abdelhafez \& El-Wahsh (2019), and Elshaer \& Nofal (2019).

The Bax protein, one of the proapoptotic members, is situated in the cytoplasm. Its structure and position are changed under the effect of injury, leading to formation of heterodimer that affects the mitochondrial membrane causing stimulation of apoptosis signaling pathway. Apoptosis consumes more energy, that in turn enhance more apoptosis producing a vicious circle (Zhao et al., 2001). Morphometric statistical analysis of Bax expression in this study revealed a significant increase in diabetic group as compared to the control one which was supported by the results of $\mathrm{Yu}$ et al. (2012).

The current study showed histopathological changes in pancreatic tissue of diabetic group that support the biochemical and physiological results, as in both exocrine and endocrine components the acini were irregularly organized, widely separated with presence of inflammatory cell infiltrations. The acinar cells appeared swollen with cytoplasmic vacuoles and dark stained nuclei. Islets of Langerhans appeared disturbed with irregular outline, and even lost. These results were similar to those of El-Esawy et al. (2016), Nurdiana et al. (2017) and Almalki et al. (2019).

Morphometric analysis of the area percent of collagen and area percent of immune-stained beta-cells of islets of Langerhans showed significant increase in diabetic group as compared to the control one.

The results of the current study confirmed that, spexin (as the standard drugs metformin and vildagliptin) utilization in the treatment of obese type 2 diabetic rats significantly ameliorated the accompanied cardiometabolic disturbances through its, anti-diabetic effects (spexin treatment decreased serum levels of both glucose and insulin, decreased insulin resistance as noticed by the decrease in HOMA-IR, and increased beta cell function as evidenced by the increase in HOMA- $\beta$ ), anti-obesity effect (spexin treatment decreased the final BMI) and hypolipidemic effects (spexin treatment improved lipid profile as it decreased the elevated serum level of TC, TG and LDL, and also decreased the atherogenic index, but it increased serum level of HDL).

These results were supported by $A l$ Daghri et al. (2019) who reported that spexin was involved in weight regulation with a potential role for therapy of obesity. Also, Walewski et al. (2014), Ge et al. (2016) and Lin et al. (2018) stated that the long-term injection of spexin, in obese rats, reduced caloric intake, body weight and serum cholesterol level. In 
addition, Ge et al. (2016) found that spexin reduced long chain fatty acids uptake by adipocytes and improved both glucose tolerance and insulin resistance in obese type 2 diabetic mice.

Moreover, Kolodziejski et al. (2018b) who declared that spexin stimulated uptake of glucose in human adipocytes. In diabetic metformin treated and diabetic vildagliptin treated groups apparent improvement in histopathological changes was noticed. As regard to the diabetic spexin treated group obvious amelioration in the histological structure of the cardiac muscle and a picture nearly similar to the normal was noticed this is similar to the results of Yu et al. (2012) who proved the protective effect of curcumin in diabetic cardiomyopathy, by improving the oxidative stress and the metabolic disorders.

Also, there was a significant decrease in Bax expression in diabetic metformin treated, diabetic vildagliptin treated and diabetic spexin treated groups as compared to the diabetic group which ensured the protective effect of the standard drugs (metformin and vildagliptin) in addition to spexin, in ameliorating the diabetic cardiac effects, this was in agreement with the results of EI-shaer and Nofal (2019) who proved the role of the anti-diabetic effect of the medicinal plant (chamomile) in improving the cardiac muscle histological structure.

In addition, the present study reported that spexin may exert its effects through, affecting DPP-IV pathway (spexin treatment decreased serum level of DPPIV and thus it could decrease the degradation of glucagon-like peptide-1), its anti-inflammatory effects (spexin treatment decreased the elevated serum level of both TNF $\alpha$ and IL-1 $\beta$ ), its antioxidant effects (spexin treatment increased serum level of SOD but decreased serum level of MDA) and its cardio-protective effects (spexin treatment decreased serum level of both LDH and CK-MB, and decreased MABP). All these effects of spexin (as the standard drugs metformin and vildagliptin) treatment were statistically significant in comparison with the diabetic group. These results were supported by Sassek et al. (2018) who stated that spexin regulated insulin secretion and pancreatic beta cell viability and proliferation.

Also, histopathological findings in diabetic treated groups with either spexin or standard drugs (metformin and vildagliptin) ensured marked improvement in changes in pancreatic tissue when compared with diabetic group. In metformin treated diabetic rats, regeneration of the islet cells with nearly regular outline and slight normal appearance of most cells was observed which was in accordance with results of El-Soud et al. (2016) who compared the effect of metformin versus honey on betacells of pancreas. Also, vildagliptin treated diabetic rats showed approximately normal organization and restoration of the islets' size, also the exocrine part showed decrease in vacuoles and trophic changes. These results were similar to those of Hassan et al. (2019) who proved the protective effect of 


\section{EFFECT OF SPEXIN TREATMENT ON CARDIOMETABOLIC CHANGES...}

Egyptian honey bee compared with vildagliptin in diabetic rat.

In spexin treated diabetic rats a picture nearly similar to that of control group, with restoration of the borders between the exocrine and the endocrine pancreatic portions. Morphometric analysis of the area percent of collagen and area percent of immune-stained beta-cells of islets of Langerhans in diabetic metformin treated, diabetic vildagliptin treated and diabetic spexin treated groups showed a significant decrease as compared with the diabetic group. These results were in line with Abunasef et al. (2014) who proved the protective effect of caffeine on the histochemical and histological alterations of beta-cells in diabetic rats. In addition, Domouky et al. (2017) proved a significant increase of collagen deposition in pancreas of diabetic rats versus mesenchymal stem cell and insulin producing cell treated rats. Also, Lin et al. (2018) confirmed that spexin had antioxidant activity as it significantly reduced MDA serum level which is a marker of lipid peroxidation in different organs including the heart. In addition, Liu et al. (2019) reported that spexin was expressed in the heart and that it had a protective effect on cardiomyocytes from hypoxia-induced metabolic dysfunction. Moreover, Toll et al. (2012) found that spexin modulated arterial blood pressure regulation.

Limitations of this study included that it was achieved on rats and the results obtained may be different from human. Also, small numbers of rats were used. Moreover, absence of healthy control groups treated with metformin, vildagliptin or spexin for comparisons.
Furthermore, changes in serum level of glucagon-like peptide-1 were not assessed. In addition, electrocardiogram changes in different groups were not recorded. Thus, further studies should be conducted to confirm the current results.

\section{CONCLUSION}

Spexin ameliorated diabetes induced deleterious cardiometabolic, histopathological and morphometric disturbances. The anti-obesity, DPP-IV inhibitory, hypoglycemic, hypolipidemic, antioxidant, anti-inflammatory and cardioprotective properties of spexin may contribute to its useful effects. These findings give an insight into pathophysiology of diabetes induced cardiometabolic disturbances and render spexin as a potential therapeutic target.

\section{ACKNOWLEDGEMENT}

The authors are grateful to Physiology, Anatomy and Biochemistry Departments in Zagazig Faculty of Medicine for supporting the experimental study to be achieved.

\section{CONFLICT OF INTEREST}

Nothing.

\section{REFERENCES}

1. Abdelhafez HM, and El-Wahsh AMSE-DA (2019): Hypolipidemic Effects of Aphanizomenon flos-aquae and Slimquick on Cardiac Muscle Fibers of the Adult Male Albino Rats. The Egyptian Journal of Hospital Medicine, 77(3): 5258-5275.

2. Abdelrahim EA (2013): Histopathological change of the endocrine pancreas in male albino rat treated with the atypical antipsychotic clozapine. Romanian journal of morphology and embryology = Revue roumaine de morphologie et embryologie, 54(2): 385-394 
3. Abunasef SK, Amin HA, and AbdelHamid GA (2014): A histological and immunohistochemical study of beta cells in streptozotocin diabetic rats treated with caffeine. Folia Histochem Cytobiol, 52(1): 42-50.

4. Al-Daghri NM, Al-Hazmi HA, Al-Ajlan A, Masoud MS, Al-Amro A, Al-Ghamdi A, Alnaami AM, Al-Attas OS, and Alokail MS (2018a): Associations of Spexin and cardiometabolic parameters among women with and without gestational diabetes mellitus. Saudi Journal of Biological Sciences, 25(4): 710-714.

5. Al-Daghri NM, Alenad A, Al-Hazmi H, Amer OE, Hussain SD, and Alokail MS (2018b): Spexin Levels Are Associated with Metabolic Syndrome Components. Dis Markers, 2018: 1679690-1679690.

6. Al-Daghri NM, Sabico S, Al-Hazmi H, Alenad AM, Al-Amro A, Al-Ghamdi A, Hussain SD, Chrousos G, and Alokail MS (2019): Circulating spexin levels are influenced by the presence or absence of gestational diabetes. Cytokine, 113: 291-295.

7. Almalki DA, Alghamdi SA, and Al-Attar AM (2019): Comparative Study on the Influence of Some Medicinal Plants on Diabetes Induced by Streptozotocin in Male Rats. BioMed Research International: 1-11.

8. Almass AA, Mohamed AO, and Abdalla OE (2016): Quercetin Curtails Obesity and Dyslipidemia, but Not Insulin Resistance in Long-Term Type 2 Diabetic Male Wistar Rats Fed the High-Fat, High-Sucrose Diet. Adv Pharmacoepidemiol Drug Saf, 5: 6-14.

9. American Diabetes A (2010): Diagnosis and classification of diabetes mellitus. Diabetes Care, 33 Suppl 1(Suppl 1): S62-S69.

10. Bancroft J, and Gamble $M$ (2008): Connective tissue stains. Theory and Practice of Histological Techniques. J. Bancroft, editor. Pbl. Churchill-Livingston Elsevier, London: 135-160.

11. Boudina S, and Abel ED (2010): Diabetic cardiomyopathy, causes and effects. Reviews in endocrine \& metabolic disorders, 11(1): 31-39.
12. Cha MC, Chou CJ, and Boozer CN (2000): High-fat diet feeding reduces the diurnal variation of plasma leptin concentration in rats. Metabolism, 49(4): 503-507.

13. Domouky AM, Hegab AS, Al-Shahat A, and Raafat N (2017): Mesenchymal stem cells and differentiated insulin producing cells are new horizons for pancreatic regeneration in type I diabetes mellitus. The international journal of biochemistry \& cell biology, 87: 77-85.

14. El-Esawy BH, Alghamdy AN, El Askary A, and E.M. E (2016): Histopathological evaluation of the pancreas following administration of paricalcitol in alloxaninduced diabetic wistar rats. World. J. Pharm. Pharmac. Sci. , 5: 189-198.

15. El-Shaer NH, and Nofal AE (2019): The Enhancing Effect of Chamomile on Histological and Immunohistochemical Alterations in Diabetic Rats. Egyptian Academic Journal of Biological Sciences, D. Histology \& Histochemistry, 11(1): 15-32.

16. El-Soud NHA, El-Laithy NA, Mohamed N, Youness ER, Wasseif ME, Yassen N, and Abdel-Latif AM (2016): Honey versus metformin: Effects on pancreatic beta- cells in streptozotocin induced diabetic rats. Der Pharma Chemica, 8: 29-39.

17. Friedewald WT, Levy RI, and Fredrickson DS (1972): Estimation of the concentration of low-density lipoprotein cholesterol in plasma, without use of the preparative ultracentrifuge. Clinical chemistry, 18(6): 499-502.

18. Ge JF, Walewski JL, Anglade D, and Berk PD (2016): Regulation of Hepatocellular Fatty Acid Uptake in Mouse Models of Fatty Liver Disease with and without Functional Leptin Signaling: Roles of NfKB and SREBP-1C and the Effects of Spexin. Semin Liver Dis, 36(4): 360-372.

19. Giorgino $F$, Leonardini $A$, and Laviola $L$ (2013): Cardiovascular disease and glycemic control in type 2 diabetes: now that the dust is settling from large clinical trials. Ann N Y Acad Sci, 1281(1): 36-50. 
EFFECT OF SPEXIN TREATMENT ON CARDIOMETABOLIC CHANGES...

20. Gu L, Ma Y, Gu M, Zhang Y, Yan S, Li N, Wang Y, Ding X, Yin J, Fan N, and Peng $Y$ (2015): Spexin peptide is expressed in human endocrine and epithelial tissues and reduced after glucose load in type 2 diabetes. Peptides, 71: 232-239.

21. Hassan AK, El-kotby DA, Tawfik MM, Badr RE, and Bahgat IM (2019): Antidiabetic effect of the Egyptian honey bee (Apis mellifera) venom in alloxan-induced diabetic rats. The Journal of Basic and Applied Zoology, 80(1): 58-67.

22. Hermans MP, Levy JC, Morris RJ, and Turner RC (1999): Comparison of insulin sensitivity tests across a range of glucose tolerance from normal to diabetes. Diabetologia, 42(6): 678-687.

23. Ji LN, Pan CY, Lu JM, Li H, Zhu DL, Li Q, Li QF, Peng YD, Tian HM, Yao C, Zhao ZG, Wang L, and Wang BH (2016): Efficacy and safety of combination therapy with vildagliptin and metformin versus metformin uptitration in Chinese patients with type 2 diabetes inadequately controlled with metformin monotherapy: a randomized, open-label, prospective study (VISION). Diabetes Obes Metab, 18(8): 775-782.

24. Kayamori F, and Igarashi K (1994): Effects of dietary nasunin on the serum cholesterol level in rats. Bioscience, biotechnology, and biochemistry, 58(3): 570571.

25. Kiernan JA (1999): Histological and histochemical methods: theory and practice. Shock, 12(6): 479-492.

26. Kirino Y, Sato Y, Kamimoto T, Kawazoe K, Minakuchi K, and Nakahori Y (2009): Interrelationship of dipeptidyl peptidase IV (DPP4) with the development of diabetes, dyslipidaemia and nephropathy: a streptozotocin-induced model using wild-type and DPP4-deficient rats. J Endocrinol, 200(1): 53-61.

27. Kolodziejski PA, Pruszynska-Oszmalek E, Korek E, Sassek M, Szczepankiewicz D, Kaczmarek P, Nogowski L, Mackowiak P, Nowak KW, Krauss H, and Strowski MZ (2018a): Serum levels of spexin and kisspeptin negatively correlate with obesity and insulin resistance in women. Physiol Res, 67(1): 45-56.

28. Kolodziejski PA, Pruszynska-Oszmalek E, Micker M, Skrzypski M, Wojciechowicz T, Szwarckopf P, Skieresz-Szewczyk K, Nowak KW, and Strowski MZ (2018b): Spexin: A novel regulator of adipogenesis and fat tissue metabolism. Biochim Biophys Acta Mol Cell Biol Lipids, 1863(10): 12281236.

29. Kumar S, Hossain J, Nader N, Aguirre R, Sriram S, and Balagopal PB (2016): Decreased Circulating Levels of Spexin in Obese Children. J Clin Endocrinol Metab, 101(7): 2931-2936.

30. Kumar S, Hossain MJ, Javed A, Kullo IJ, and Balagopal PB (2018): Relationship of circulating spexin with markers of cardiovascular disease: a pilot study in adolescents with obesity. Pediatric obesity, 13(6): 374-380.

31. Lamers D, Famulla S, Wronkowitz N, Hartwig S, Lehr S, Ouwens DM, Eckardt K, Kaufman JM, Ryden M, Muller S, Hanisch FG, Ruige J, Arner P, Sell H, and Eckel J (2011): Dipeptidyl peptidase 4 is a novel adipokine potentially linking obesity to the metabolic syndrome. Diabetes, 60(7): 1917-1925.

32. Li Y, Song B, and Xu C (2018): Effects of Guanfu total base on Bcl-2 and Bax expression and correlation with atrial fibrillation. Hellenic journal of cardiology : $\mathrm{HJC}=$ Hellenike kardiologike epitheorese, 59(5): 274-278.

33. Lin C-Y, Zhao L, Huang T, Lu L, Khan M, Liu J, Zhong LLD, Cai Z-W, Fan B-M, Wong AOL, and Bian Z-X (2018): Spexin Acts as Novel Regulator for Bile Acid Synthesis. Front Physiol, 9: 378-378.

34. Liu Y, Sun L, Zheng L, Su M, Liu H, Wei Y, Li D, Wang Y, Dai C, Gong Y, Zhao C, and Li Y (2019): Spexin protects cardiomyocytes from hypoxia-induced metabolic and mitochondrial dysfunction. Naunyn Schmiedebergs Arch Pharmacol, 1-9.

35. Mithieux G, Rajas F, and Zitoun C (2006): Glucose utilization is suppressed in the gut of 
insulin-resistant high fat-fed rats and is restored by metformin. Biochem Pharmacol, 72(12): 1757-1762.

36. Novelli E, Diniz Y, Galhardi C, Ebaid G, Rodrigues H, Mani F, Fernandes AAH, Cicogna AC, and Novelli Filho J (2007): Anthropometrical parameters and markers of obesity in rats. Laboratory animals, 41(1): 111-119.

37. Nurdiana S, Goh YM, Ahmad H, Dom SM, Syimal'ain Azmi N, Noor Mohamad Zin NS, and Ebrahimi M (2017): Changes in pancreatic histology, insulin secretion and oxidative status in diabetic rats following treatment with Ficus deltoidea and vitexin. BMC Complementary and Alternative Medicine, 17(1): 290-307.

38. Oliveira PW, de Sousa GJ, Caliman IF, Lamas AZ, Santos de Medeiros AR, de Andrade TU, de Abreu GR, de Figueiredo SG, and Bissoli NS (2014): Metformin ameliorates ovariectomy-induced vascular dysfunction in non-diabetic Wistar rats. Clinical science (London, England : 1979), 127(4): 265-275.

39. Omar AI, and Aboulkhair AG (2017): Effect of Bone Marrow Versus Adipose Tissue Derived Mesenchymal Stem Cells on the Pancreas of Streptozotocin-Induced Diabetes Mellitus Type I in Adult Male Rats (Histological Study). Egyptian Journal of Histology, 40(1): 12-24.

40. Rajesh KS, Ipseeta RM, Ujwala M, Manjusha KB, and Deshmukh YA (2017): Cardiometabolic Efficacy and Mechanisms of Berberine in Experimentally Induced Changes in Diabetes and Metabolic Syndrome Rats. EC Pharmacology and Toxicology, 5(3): 122-133.

41. Rutter MK, and Nesto RW (2011): Blood pressure, lipids and glucose in type 2 diabetes: how low should we go? Rediscovering personalized care. European heart journal, 32(18): 2247-2255.

42. Sakamaki T, Tajima Y, Ichikawa S, and Murata K (1987): Measurement of mean arterial pressure in rats by a tail-cuff method with sensitive photoelectric sensors. Jikken Dobutsu, 36(4): 409-414.
43. Sassek M, Kolodziejski PA, Strowski MZ, Nogowski L, Nowak KW, and Mackowiak P (2018): Spexin Modulates Functions of Rat Endocrine Pancreatic Cells. Pancreas, 47(7): 904-909.

44. Silva Júnior WS, Souza MdGC, Nogueira Neto JF, Bouskela E, and Kraemer-Aguiar LG (2019): Dipeptidyl Peptidase 4 Activity Is Related to Body Composition, Measures of Adiposity, and Insulin Resistance in Subjects with Excessive Adiposity and Different Degrees of Glucose Tolerance. J Diabetes Res, 2019: 5238013-5238013.

45. Suman RK, Ray Mohanty I, Borde MK, Maheshwari U, and Deshmukh YA (2016): Development of an Experimental Model of Diabetes Co-Existing with Metabolic Syndrome in Rats. Advances in Pharmacological Sciences, 2016: 11.

46. Sun G, Bishop J, Khalili S, Vasdev S, Gill V, Pace D, Fitzpatrick D, Randell E, Xie Y-G, and Zhang H (2007): Serum visfatin concentrations are positively correlated with serum triacylglycerols and down-regulated by overfeeding in healthy young men. The American journal of clinical nutrition, 85(2): 399-404.

47. Thent ZC, Lin TS, Das S, and Zakaria Z (2012): Histological changes in the heart and the proximal aorta in experimental diabetic rats fed with Piper sarmentsoum. Afr J Tradit Complement Altern Med, 9(3): 396-404.

48. Toll L, Khroyan TV, Sonmez K, Ozawa A, Lindberg I, McLaughlin JP, Eans SO, Shahien AA, and Kapusta DR (2012): Peptides derived from the prohormone proNPQ/spexin are potent central modulators of cardiovascular and renal function and nociception. Faseb j, 26(2): 947-954.

49. Walewski JL, Ge F, Gagner M, Inabnet WB, Pomp A, Branch AD, and Berk PD (2010): Adipocyte accumulation of longchain fatty acids in obesity is multifactorial, resulting from increased fatty acid uptake and decreased activity of genes involved in fat utilization. Obesity surgery, 20(1): 93-107.

50. Walewski JL, Ge F, Lobdell Ht, Levin N, Schwartz GJ, Vasselli JR, Pomp A, Dakin G, and Berk PD (2014): Spexin is a novel 
EFFECT OF SPEXIN TREATMENT ON CARDIOMETABOLIC CHANGES...

human peptide that reduces adipocyte uptake of long chain fatty acids and causes weight loss in rodents with diet-induced obesity. Obesity (Silver Spring), 22(7): 1643-1652.

51. Wright AK, Kontopantelis E, Emsley R, Buchan I, Mamas MA, Sattar N, Ashcroft DM, and Rutter MK (2019): Cardiovascular Risk and Risk Factor Management in Type 2 Diabetes Mellitus. Circulation, 139(24): 2742-2753.

52. Yu W, Wu J, Cai F, Xiang J, Zha W, Fan D, Guo S, Ming Z, and Liu C (2012):
Curcumin alleviates diabetic cardiomyopathy in experimental diabetic rats. PloS one, 7(12): e52013.

53. Zhao ZQ, Velez DA, Wang NP, HewanLowe KO, Nakamura M, Guyton RA, and Vinten-Johansen J (2001): Progressively developed myocardial apoptotic cell death during late phase of reperfusion. Apoptosis, 6(4): 279-290. 
تأثير العلاج باستخدام الإسبيكسن على التخيرات في القلب

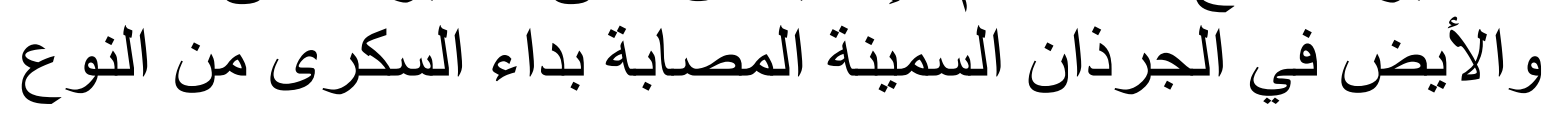
الثانى

خالد عبد الفتاح ابو الفضل'، نور الهدى عبد العزيز محمد'، رضوى محمود السيد'،

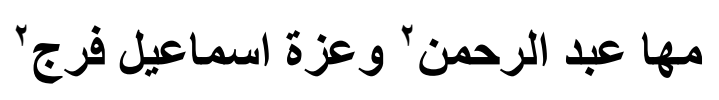

' ل القسم الفسيولوجيا الطبية، كلية الطب، جامعة الزقازيق

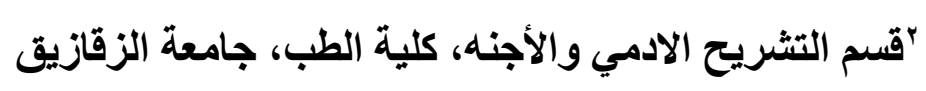

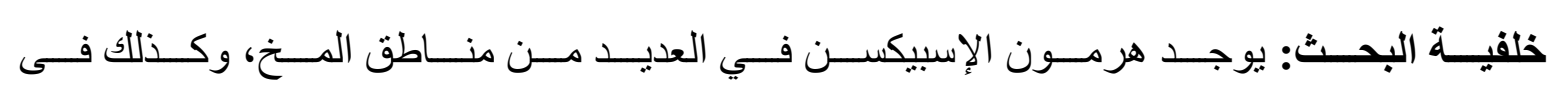

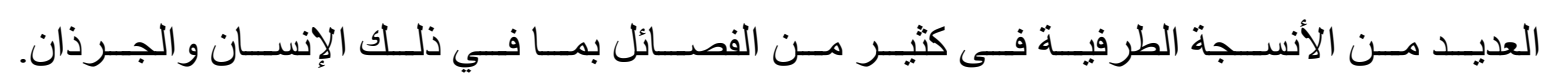

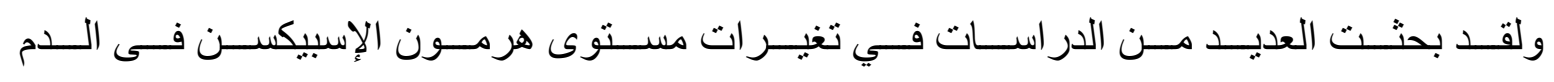

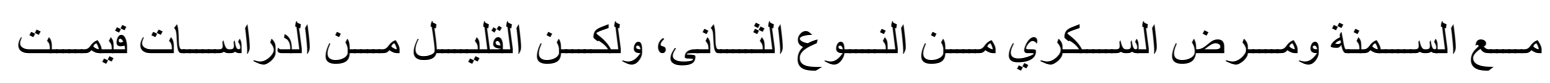

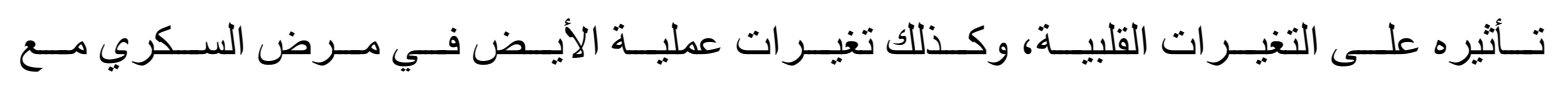
وجود بعض الثباين في نتائج تلك الدراسات.

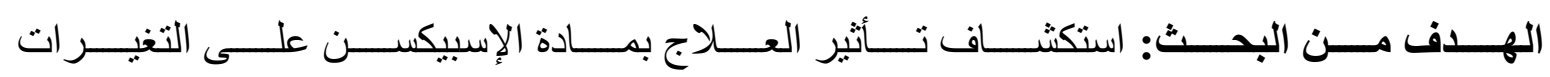

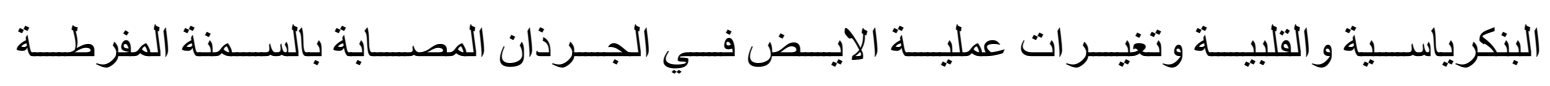

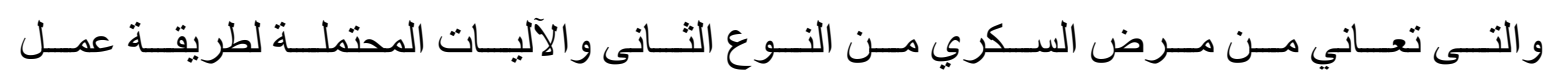

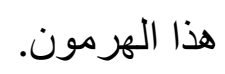

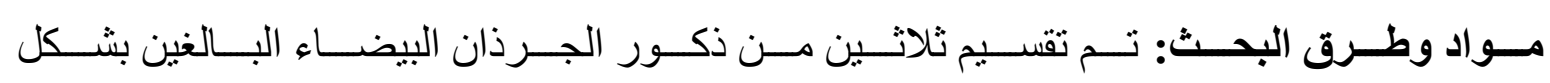
عشو ائي إلى 0 مجمو عات متساوية:

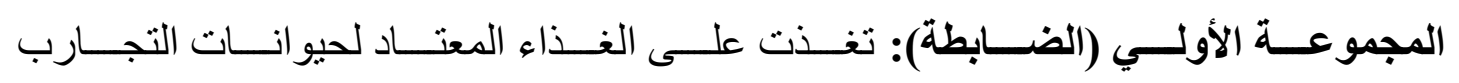

$$
\text { طو ال مدة هذه الدر اسة (^ أسابيع). }
$$

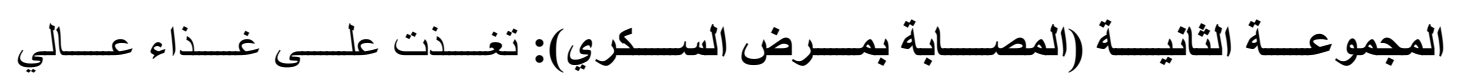

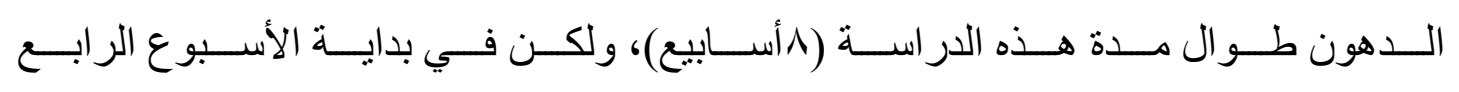

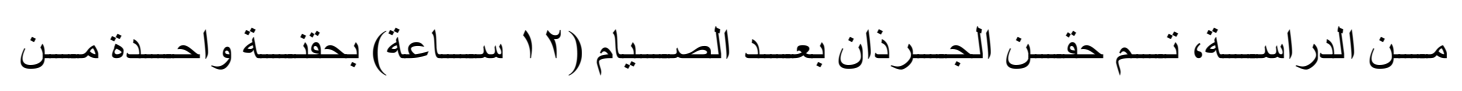

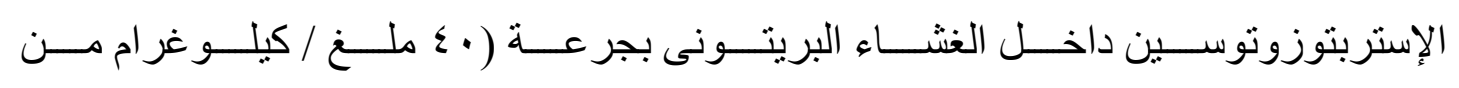




\section{EFFECT OF SPEXIN TREATMENT ON CARDIOMETABOLIC CHANGES... 757}

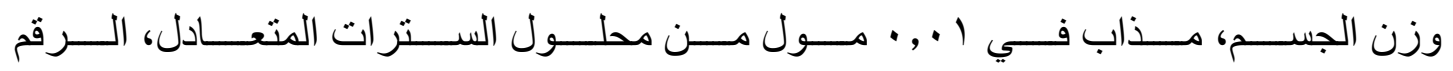
الهيدروجيني 0, ؛) ) لإحداث مرض السكري من النوع الثانى.

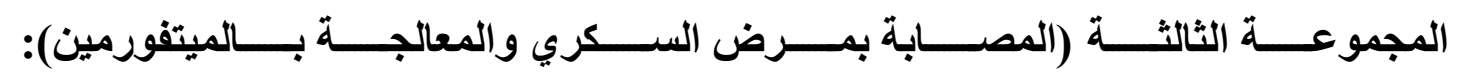

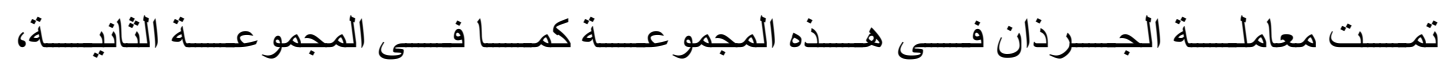

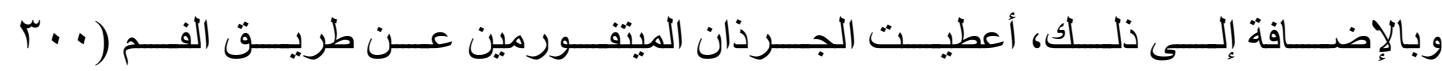

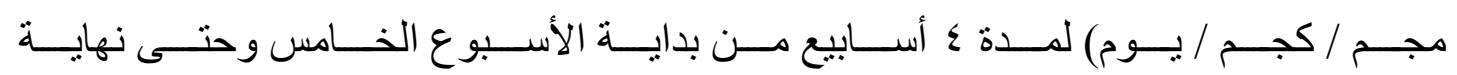

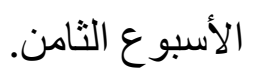

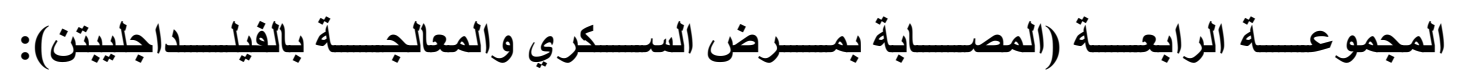

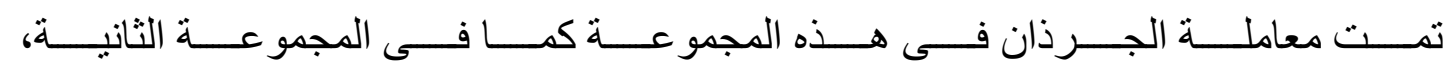

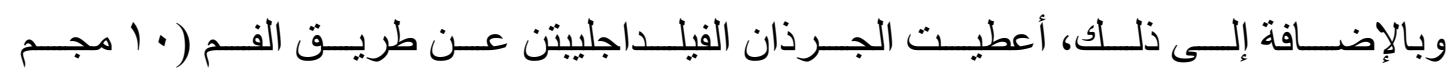

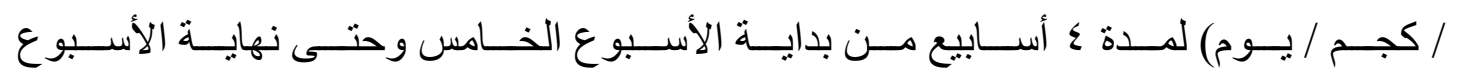

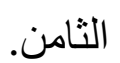

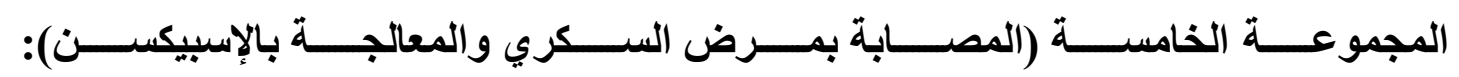

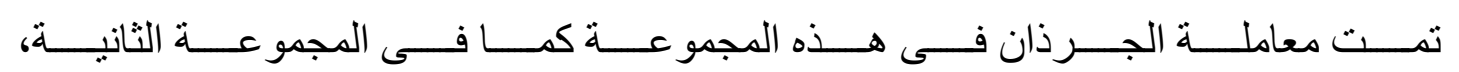

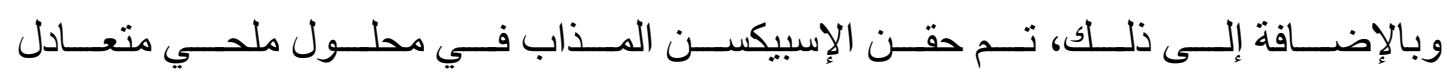

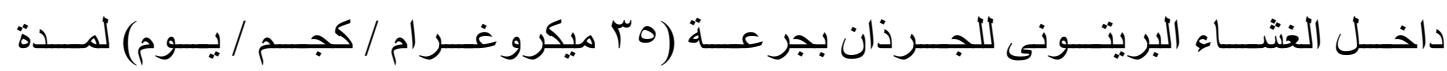

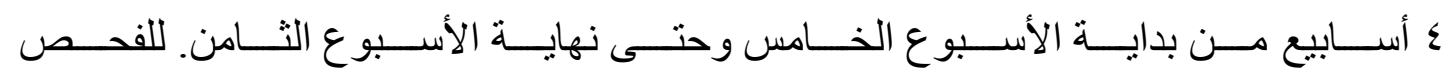

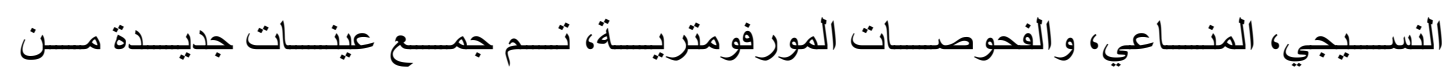
القلب و البنكرياس من الفئران التي تم التضحية بها.

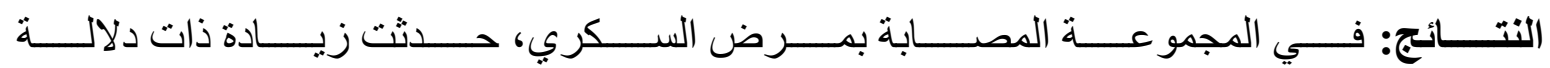

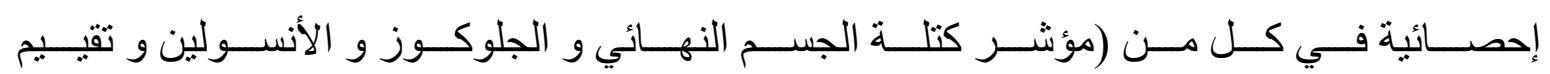

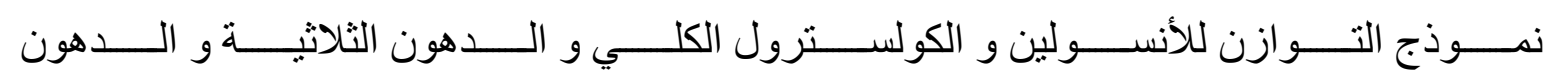

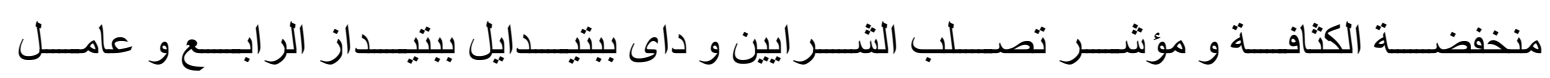

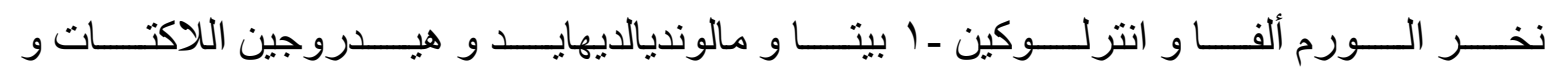

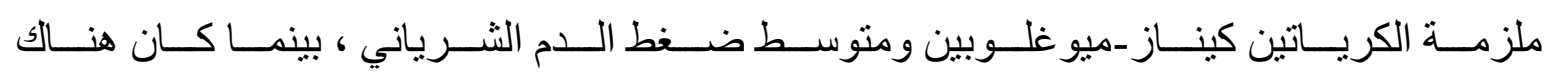

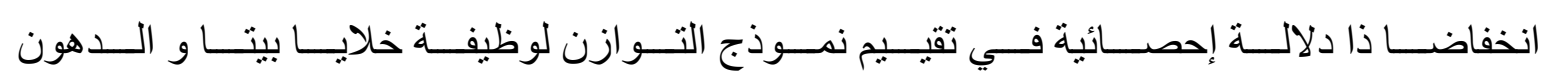

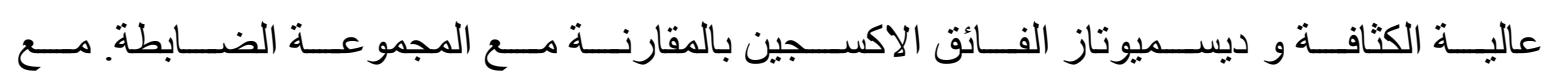

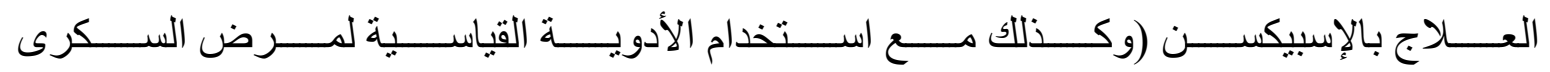




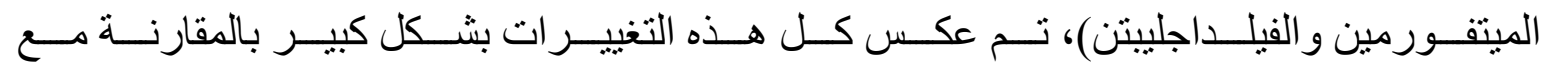

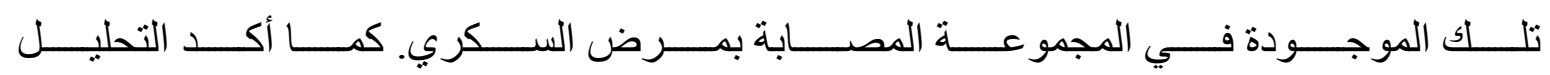

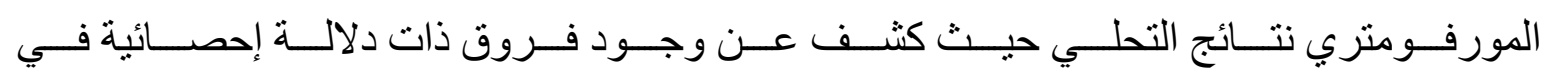

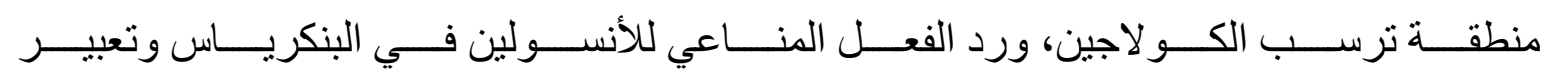

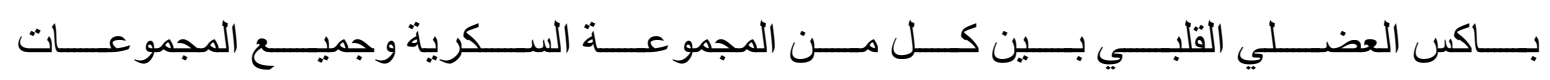

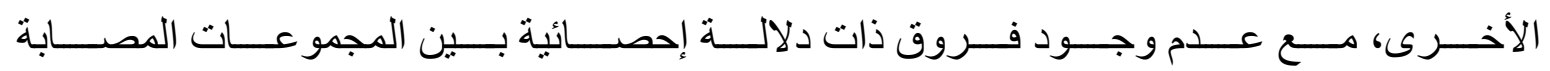
بالسكرى المعالجة بالميتفورمين أو بالفيلاجاجيتن أو بالإسبيكسن.

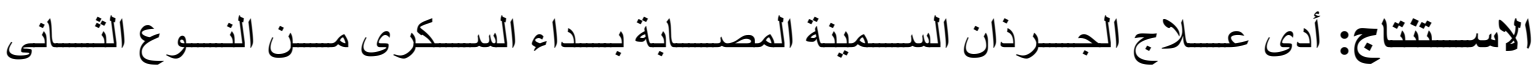

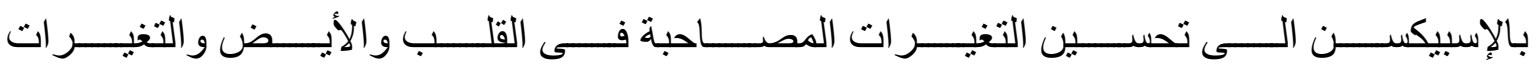

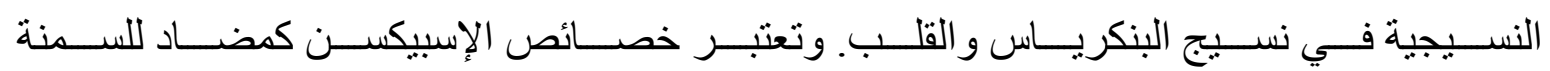

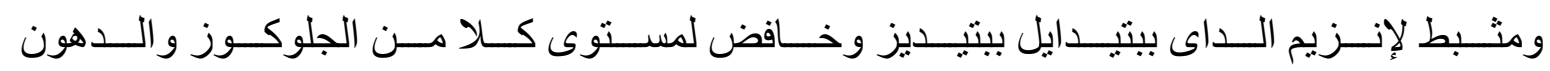

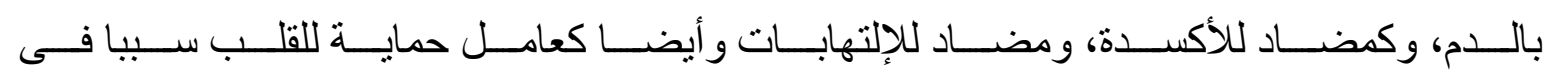
تأثير اته المفيدة. 